UNIVERSIDADE DE SÃO PAULO

ESCOLA DE ENFERMAGEM

KÁTIA DARBELLO DA SILVA

LINHA DE CUIDADO PARA PREVENÇÃO E ENFRENTAMENTO DA VIOLÊNCIA NAS RELAÇÕES DE INTIMIDADE ENTRE ADOLESCENTES

SÃO PAULO 


\title{
LINHA DE CUIDADO PARA PREVENÇÃO E ENFRENTAMENTO DA VIOLÊNCIA NAS RELAÇÕES DE INTIMIDADE ENTRE ADOLESCENTES
}

\begin{abstract}
Versão corrigida da Dissertação apresentada ao Programa de Pós-Graduação Mestrado Profissional em Enfermagem na Atenção Primária em Saúde no Sistema Único de Saúde da Escola de Enfermagem da Universidade de São Paulo para obtenção do título de Mestra em Ciências
\end{abstract}

Área de concentração: Cuidado em Saúde

Orientadora: Profa ${ }^{a}$ Dra . Rosa Maria Godoy Serpa da Fonseca

\section{VERSÃO CORRIGIDA}

A versão corrigida encontra-se disponível na Biblioteca da Escola de Enfermagem da Universidade de São Paulo e na Biblioteca Digital de Teses e Dissertações da Universidade de São Paulo.

\author{
São Paulo
}


AUTORIZO A REPRODUÇÃO E DIVULGAÇÃO TOTAL OU PARCIAL DESTE TRABALHO, POR QUALQUER MEIO CONVENCIONAL OU ELETRÔNICO, PARA FINS DE ESTUDO E PESQUISA, DESDE QUE CITADA A FONTE.

Assinatura:

Data:

\section{Catalogação na Publicação (CIP)}

Biblioteca "Wanda de Aguiar Horta"

\section{Escola de Enfermagem da Universidade de São Paulo}

Silva, Kátia Darbello da

Linha de cuidado para prevenção e enfrentamento da violência nas relações de intimidade entre adolescentes / Kátia Darbello da Silva. São Paulo, 2016.

$118 \mathrm{p}$.

Dissertação (Mestrado) - Escola de Enfermagem da Universidade de São Paulo.

Orientadora: Prof. ${ }^{\mathrm{a}}$ Dr. ${ }^{\mathrm{a}}$ Rosa Maria Godoy Serpa da Fonseca

Área de concentração: Cuidado em Saúde

1. Violência. 2. Violência contra a mulher. 3. Assistência à Saúde. 4. Políticas públicas. 5. Enfermagem. I. Título. 
Nome: Kátia Darbello da Silva

Titulo: Linha de Cuidado para prevenção e enfrentamento da violência nas relações de intimidade entre adolescentes

Dissertação apresentada ao Programa de Pós-Graduação Mestrado Profissional em Enfermagem na Atenção Primária em Saúde no Sistema Único de Saúde da Escola de Enfermagem da Universidade de São Paulo para obtenção do título de Mestra em Ciências

Aprovado em:

\section{Banca Examinadora}

Prof. Dr. Instituição:

Julgamento: Assinatura:

Prof. Dr. Instituição:

Julgamento: Assinatura:

Prof. Dr. Instituição:

Julgamento: Assinatura: 


\section{DEDICATÓRIA}

Aos meus pais, meus maiores incentivadores, meus exemplos de vida e de amor.

A minha irmã, minha companheira e cúmplice.

Ao meu esposo, que sempre acreditou em mim mais do que eu mesma, sempre me incentivando a ser melhor. 


\section{AGRADECIMENTOS}

Agradeço a Deus, porque sempre esteve presente em toda a minha vida.

A minha orientadora, Prof ${ }^{\mathrm{a}}$ Dr $^{\mathrm{a}}$ Rosa Maria Godoy Serpa da Fonseca, por todos os ensinamentos e por toda a dedicação e incentivo neste período de estudo.

A todos os funcionários da EEUSP, em especial aos do Departamento de Saúde Coletiva (ENS) pela acolhida.

A todas as colegas do grupo de pesquisa Gênero, Saúde e Enfermagem em especial à Prof ${ }^{\underline{a}}{ }^{-2}{ }^{\text {a }}$ Maíra.

A Secretaria da Saúde do município de Guarulhos, por me proporcionar campo de estudo para o trabalho.

As minhas chefes, Antonia Maria Peres de Carvalho e Viviane Haddad Silva Higuchi, que além de me liberarem para estudar, sempre me apoiaram e auxiliaram no que eu necessitei para completar esta jornada.

Aos funcionários da Unidade Básica de Saúde Nova Cidade, que souberam entender minhas ausências, especialmente a Beatriz Lumena Tão Búzio e Daniela Alves Bezerra, imprescindíveis para que tudo se tornasse possível.

Aos meus pais, Ana e Zezinho, que sempre me apoiaram em tudo, e que são a razão da minha vida.

A minha irmã Paola, por sempre me fazer entender que é necessário rir.

Ao meu companheiro de vida, José, por sempre acreditar e me mostrar o quanto tem o orgulho de mim. 
As minhas eternas crianças, Isadora, Murilo, Sophia e Manu, meu refúgio nos momentos difíceis.

Aos meus amigos e familiares, Andreza, Diego, Fernanda, Kelly, Luciana, Paula, Suzana, pela amizade e confiança.

As minhas amigas de graduação EEUSP, Bia, Camila, Cláudia, Taís, Vanessa, por toda diversão que é falar com vocês.

A todos que de alguma maneira contribuíram para que o sonho se tornasse realidade, meu carinho e meu obrigada!!! 
"Pensamos demasiadamente, sentimos muito pouco, necessitamos mais de humildade que de máquinas. Mais de bondade e ternura que de inteligência. Sem isso, a vida se tornará violenta e tudo se perderá" (Charles Chaplin) 
Silva, KD. Linha de Cuidado para prevenção e enfrentamento da violência nas relações de intimidade entre adolescentes [dissertação]. São Paulo: Escola de Enfermagem, Universidade de São Paulo; 2016.

\section{RESUMO}

Introdução: A violência é um tema preocupante na atenção a saúde do adolescente, recorre a preocupação com 0 crescente envolvimento desta faixa etária em diferentes estatísticas sobre violência, incluindo a violência de gênero. Objetivos: Desenvolver uma linha de cuidado para prevenção da violência de gênero entre os adolescentes nas relações de intimidade, baseada nas políticas públicas existentes e nas concepções dos profissionais acerca do fenômeno. Metodologia: Estudo descritivo, exploratório de abordagem qualitativa, através de questionário baseado em situação sobre violência de gênero nas relações de intimidade dos adolescentes, além de uma busca por políticas públicas que tratem deste assunto. Os referenciais teóricos utilizados foram adolescência e violência nas relações de intimidade entre adolescentes. Resultados: Foram encontradas no município políticas, decretos e leis que tratam da adolescência. Essa foi definida como uma fase conflituosa e de vulnerabilidades, utilizando a Teoria da multicausalidade para explicar a violência. Relataram diferentes práticas acerca do manejo da violência e apontaram fraco o apoio intersetorial. Conclusão: As políticas públicas são insuficientes para o apoio profissional e eles conseguem identificar essa falta de apoio. Se faz necessária a apropriação de alguns conceitos para a melhoria das ações desenvolvidas. A Linha de Cuidado proposta tem como finalidade auxiliar nessa apropriação para qualificar as práticas já existentes relatadas pelos sujeitos do estudo.

PALAVRAS-CHAVE: Violência. Adolescente. Violência por parceiro íntimo. Assistência Integral à Saúde. Políticas Públicas. 
Silva, KD. Care line for preventing and tackling violence in intimate relationships among teenagers [dissertation]. São Paulo: Escola de Enfermagem, Universidade de São Paulo; 2016.

\begin{abstract}
Introduction: Violence is a worrying issue in attention to adolescent health, rehash the concern with the increasing involvement of this age group in different statistics about violence, include the gender violence Objectives: Develop a care line to prevent the gender violence between teenagers on intimacy relations, based on existent public policies and in conceptions of professionals about the phenomenon. Methodology: A descriptive study has been conducted, exploratory of qualitative approach, through questionnaire based on the situation about gender violence in teenagers' intimate relationships, as well as a search for public policies that treat this subject. The theoretical benchmarks that supported the data analysis were adolescence and violence in intimacy relations among teenagers. Results: There were found in the city policies, decrees and laws that deal with teenager care. Professionals defined adolescence as a phase of conflictive transition and vulnerabilities. The Multicausality Theory was used to explain the violence and they brought different practices. They recognized that the intersectoral support is weak. Conclusion: Public policies are insufficient for the professional support and they can identify this lack of support. It's necessary the appropriation of some concepts for the improvement of the actions developed. The Care Line proposed has the aim to assist this ownership to qualify existing practices reported by the professionals.
\end{abstract}

KEYWORDS: Violence. Adolescent. Intimate Partner Violence. Comprehensive Health Care. Public Policies. 


\section{LISTA DE ILUSTRAÇÕES}

\section{FIGURAS}

Figura 1 - Mapa da Região Metropolitana de São Paulo........

Figura 2 - Mapa das Regiões de Saúde do Município de 34 Guarulhos

\section{GRÁFICOS}

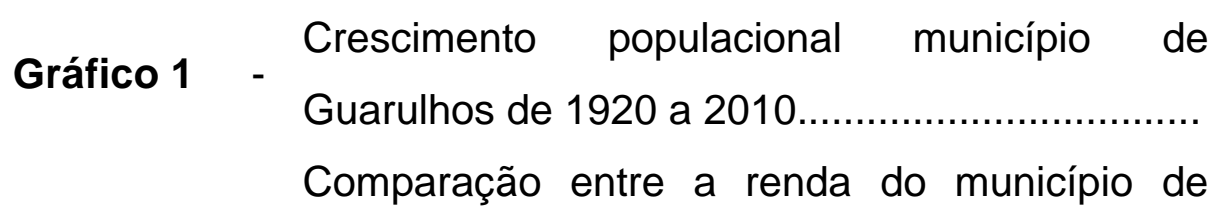
32

Gráfico 2 - Guarulhos, a Região Metropolitana de São 33 Paulo e o Estado de São Paulo

\section{QUADROS}

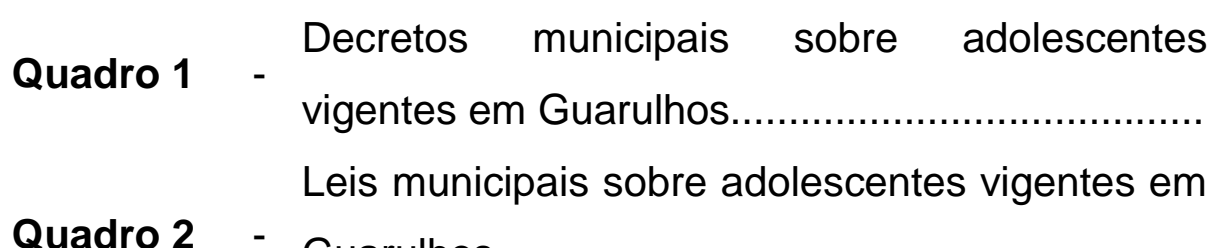
50 50

Quadro 3 - Categorias de análise e temas abordados. 


\section{LISTA DE TABELAS}

Causas de morte de acordo com o CID-10 em

Tabela 1 - Causas de mote de acordo com o CID-10 em 19

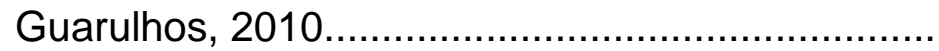

Tabela 2 - Distribuição dos participantes de acordo com a 53

formação complementar........................................ 


\section{LISTA DE ABREVIATURAS E SIGLAS}

$\begin{array}{ll}\text { AB } & \text { Atenção Básica } \\ \text { AF } & \text { Arma de fogo } \\ \text { AIDS } & \text { Síndrome da Imunodeficiência Adquirida } \\ \text { CEDAP } & \text { Centro de Diagnóstico, Ação e Prevenção } \\ \text { CID } & \text { Classificação Internacional de Doenças } \\ \text { CRAS } & \text { Centro de Referência Assistência Social } \\ \text { CREAS } & \text { Centro de Referência Especializado Assistência Social } \\ \text { DSTs } & \text { Doenças Sexualmente Transmissíveis } \\ \text { ECA } & \text { Estatuto da Criança e do Adolescente } \\ \text { IBGE } & \text { Instituto Brasileiro de Geografia e Estatística } \\ \text { NAAB } & \text { Núcleo de Apoio à Atenção Básica } \\ \text { NASF } & \text { Núcleo de Apoio à Saúde da Família } \\ \text { OMS } & \text { Organização Mundial da Saúde } \\ \text { PIB } & \text { Produto Interno Bruto } \\ \text { PMPS } & \text { Política Municipal de Promoção à Saúde } \\ \text { PSE } & \text { Programa Saúde na Escola } \\ \text { RAS } & \text { Redes de Atenção à Saúde } \\ \text { RC } & \text { Rede Cegonha } \\ \text { RM } & \text { Região Metropolitana } \\ \text { RRAS } & \text { Redes Regionalizadas de Atenção à Saúde } \\ \text { RUE } & \text { Rede de Atenção às Urgências e Emergências } \\ \text { SINAN } & \text { Sistema de Informação de Agravos de Notificação } \\ \text { SUS } & \text { Sistema Único de Saúde } \\ \text { UBS } & \text { Unidade Básica de Saúde } \\ \text { UNIFESP } & \text { Universidade Federal São Paulo } \\ \text { WEBQDA } & \text { Web Qualitative Data Analysis } \\ & \end{array}$




\section{SUMÁRIO}

1. INTRODUÇÃO............................................................ 17

1.1 VIOLÊNCIA NA ADOLESCÊNCIA ............................... 18

1.2 VIOLÊNCIA ENTRE ADOLESCENTES........................ 20

1.3 REDES DE ATENÇÃO À SAÚDE E O CONCEITO DE 21

2. OBJETIVOS............................................................. 24

3. METODOLOGIA....................................................... 26

3.1 REFERENCIAL TÉORICO - METODOLÓGICO............. 27

3.1.1 Gênero e violência de gênero na perspectiva da teoria da determinação social do processo saúde-doença $\quad 27$

3.1.2 Adolescência.......................................................... 28

3.2 CENÁRIO DE ESTUDO............................................ 30

3.3 TIPO DE ESTUDO................................................ 35

$3.4 \quad$ PRESSUPOSTOS ................................................... 36

3.5 PROCEDIMENTOS METODOLÓGICOS........................ 37

3.5.1 Coleta e organização dos dados................................... 37

3.5.2 Análise dos dados.................................................... 39

$4 \quad$ ASPECTOS ÉTICOS................................................... 41

$5 \quad$ RESULTADOS........................................................ 43

5.1 POLITICAS PUBLICAS PARA A ADOLESCENCIA EM 44 GUARULHOS.......................................................

5.1.1 Programa Saúde Na Escola (PSE)............................... 44

5.1.2 Política Municipal de Promoção à Saúde (PMPS)........... 47

5.1.3 Programa Saúde na Adolescência.................................. 49

5.1.4 Legislação encontrada................................................ 49

CONCEPÇÕES E CONHECIMENTOS DE PROFISSIONAIS DE SAÚDE ACERCA DAS

5.2 PRÁTICAS PARA PREVENÇÃO E ENFRENTAMENTO 52 DA VIOLÊNCIA ENTRE ADOLESCENTES.

5.2.1 Caracterização da Amostra........................................... 52

5.2.2 Dados qualitativos.................................................... 54

Linha de cuidado para prevenção e enfrentamento da violência nas relações de intimidade entre adolescentes

6. DISCUSSÃO. 60

7. CONSIDERAÇÕES FINAIS ................. 103

REFERÊNCIAS.................................................................. 106

APÊNDICE 1 - Questionário Caracterização da amostra............ 114

APÊNDICE 2 - Questionário de Coleta de dados....................... 115

APÊNDICE 3 - Termo de Consentimento Livre e Esclarecido.... 117 


\section{APRESENTAÇÃO}

Minha aproximação com a Saúde Coletiva aconteceu logo após o término da graduação na Escola de Enfermagem da Universidade de São Paulo, em 2009, quando iniciei meu trabalho como Enfermeira da Família no município de Guarulhos.

De 2009 a 2011, atuei em uma das áreas mais violentas do município, no que diz respeito ao tráfico de drogas e à criminalidade. Sempre me interessei pelo entendimento da dinâmica das famílias vivendo e convivendo com aquela situação.

Em 2012, assumi a gerência de uma Unidade de Saúde Básica com Estratégia Saúde da Família, que recebia alunos de graduação, principalmente medicina, de instituições de ensino particular, em diferentes períodos da formação.

Durante a convivência com os estudantes no enfrentamento de alguns problemas do território, percebi que deveria buscar formação específica para atuar junto a eles, e para qualificar tanto a minha carreira, quanto a ação junto aos futuros profissionais de saúde que ali estavam se formando.

Ingressei no Mestrado Profissional do Departamento de Saúde Coletiva da Universidade de São Paulo por entender que esta proposta beneficiaria a mim como enfermeira, mas também 0 município e a população do meu território com o produto que dessa experiência fosse formado.

Ao fazer parte do Grupo de Pesquisa Gênero, Saúde e Enfermagem, me aproximei da temática da violência de gênero entre os adolescentes nas relações de intimidade, em desenvolvimento no grupo por meio do projeto de pesquisa "Violência nas relações de intimidade envolvendo adolescentes à luz de gênero e geração: estudo multicêntrico luso-hispano-brasileiro", financiado pelo 
Conselho Nacional de Desenvolvimento Científico e Tecnológico (CNPq - Processo no 447377/2014-0). 


\section{INTRODUCÃO}




\section{INTRODUÇÃO}

\subsection{VIOLÊNCIA NA ADOLESCÊNCIA}

Em 2012, o Instituto Brasileiro de geografia e estatística (IBGE) publicou a Pesquisa Nacional de Saúde do Escolar, realizada com 109.104 estudantes do $9^{\circ}$ ano do ensino fundamental em escolas públicas e privadas de todo o território nacional. O objetivo foi conhecer e dimensionar os diversos fatores de risco e proteção relacionados à saúde dessa população. A publicação evidencia a importância de o tema violência ser pautado no contexto de atendimento à saúde desta população porque se trata de

"[...] aspecto relevante da saúde dos adolescentes
e resulta do fato de que as causas externas
(lesões, acidentes, violências etc.) são a principal
causa de morte e importante causa de sequelas e
incapacidades entre os adolescentes e jovens no
Brasil. Estas causas de morte refletem a
exposição a situações de risco vividas pelos
adolescentes e que podem ser prevenidas, em
grande parte, por mudanças no ambiente social e
no comportamento desta parcela da população"
(Brasil, 2013, p. 26).

Dos 109.104 estudantes pesquisados pelo IBGE, 10,6\% declararam que haviam sofrido recentemente agressão física por adultos da família. Com relação ao envolvimento em brigas com armas, $7,3 \%$ deles se envolveram em brigas com arma branca e $6,4 \%$ com arma de fogo. As agressões verbais sofridas no ambiente escolar também foram pesquisadas e $35,4 \%$ dos alunos declararam já terem se sentido humilhados com as provocações dos colegas de escola. Outros $20,8 \%$ declararam já ter humilhado e magoado algum de seus colegas (Brasil, 2013).

Os dados que levam a supor a alta gravidade da violência entre jovens são bastante preocupantes:

"Entre os jovens, o crescimento da mortalidade por AF (arma de fogo) foi mais intenso ainda. Se no conjunto da população, os números cresceram $387 \%$ ao longo do 
período (1990 a 2003), entre os jovens esse crescimento foi de $463,6 \%$. Também os homicídios jovens cresceram de forma mais pesada: na população como um todo foi de $556,6 \%$, mas entre os jovens o aumento foi de $655,6 \%$ " (Brasil, 2015, p. 21).

Dados obtidos do SINAN (Sistema de Informação de Agravos de Notificação) de 2011 revelam que foram atendidos no SUS e geraram notificações 73.633 pessoas vítimas de algum tipo de violência. Destas, 11.600 eram jovens de 10 a 19 anos e a maioria, cerca de 65\%, do sexo feminino (Waiselfisz, 2012).

No Município de Guarulhos, em 2010, as causas externas correspondiam à primeira causa de morte entre os jovens de $10 \mathrm{a}$ 19 , e isso se estende para as faixas etárias posteriores, como demonstrado no gráfico a seguir:

Tabela 1 - Causas de morte de acordo com o CID-10, Guarulhos, 2010

\begin{tabular}{|c|c|c|c|c|c|c|c|}
\hline Capítulo da CID-10 & 0 a 9 & 10 a 19 & 20 a 29 & 30 a 39 & 40 a 49 & 50 a 59 & $\geq 60$ \\
\hline I. Algumas doenças infecciosas e parasitárias & 10,7 & 1,9 & 8,9 & 14,0 & 33,8 & 43,7 & 102,5 \\
\hline II. Neoplasias (tumores) & 2,1 & 7,4 & 9,3 & 16,9 & 63,5 & 203,9 & 683,7 \\
\hline III. Doenças sangue órgãos hemat e transt imunitár & 1,1 & 1,4 & 1,8 & 2,9 & 0 & 4,3 & 12,9 \\
\hline IV. Doenças endócrinas nutricionais e metabólicas & 0,5 & 0,9 & 1,3 & 2,4 & 7,1 & 28,3 & 213,0 \\
\hline V. Transtornos mentais e comportamentais & 0 & 0 & 0,4 & 0 & 2,4 & 2,6 & 25,9 \\
\hline VI. Doenças do sistema nervoso & 8,0 & 1,4 & 2,7 & 5,3 & 5,3 & 10,3 & 72,7 \\
\hline IX. Doenças do aparelho circulatório & 3,7 & 2,3 & 9,3 & 31,8 & 122,2 & 317,8 & 1614,3 \\
\hline X. Doenças do aparelho respiratório & 16,1 & 2,8 & 7,5 & 14,9 & 37,4 & 91,7 & 644,9 \\
\hline XI. Doenças do aparelho digestivo & 2,7 & 0,5 & 2,7 & 17,3 & 42,7 & 84,0 & 204,0 \\
\hline XII. Doenças da pele e do tecido subcutâneo & 0 & 0 & 0,4 & 0 & 0 & 1,7 & 15,9 \\
\hline XIII.Doenças sist osteomuscular e tec conjuntivo & 0 & 0 & 0 & 0,5 & 4,2 & 0,9 & 18,9 \\
\hline XIV. Doenças do aparelho geniturinário & 0 & 0,9 & 0 & 1,9 & 1,8 & 20,6 & 106,5 \\
\hline XV. Gravidez parto e puerpério & 0 & 0 & 2,2 & 1,4 & 0,6 & 0 & 0 \\
\hline XVI. Algumas afec originadas no período perinatal & 79,2 & 0 & 0 & 0 & 0 & 0 & 0 \\
\hline XVII.Malf cong deformid e anomalias cromossômicas & 36,9 & 0,5 & 1,3 & 1,0 & 0 & 0 & 1,0 \\
\hline XVIII.Sint sinais e achad anorm ex clín e laborat & 1,6 & 0 & 3,6 & 5,8 & 6,5 & 6,9 & 15,9 \\
\hline XX. Causas externas & 15,0 & 35,8 & 84,8 & 74,2 & 66,4 & 70,3 & 120,4 \\
\hline
\end{tabular}

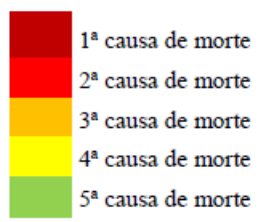

Fonte: Guarulhos. Secretaria da Saúde. Política Municipal de Promoção à Saúde. 2014.

Em 2012, nesse município, o número de jovens era de 335.540 pessoas e a taxa de homicídios, de 40,8/100 mil habitantes. 
Comparando-se com a taxa de homicídios para a população em geral que foi de 21,5/100 mil habitantes no mesmo ano, pode-se reconhecer a necessidade de enfrentamento de todas as formas de violência na adolescência no Município (Brasil, 2013).

Dentre as diferentes formas de violência existentes, na adolescência também pode ser encontrada a violência nas relações de intimidade entre adolescentes.

\subsection{VIOLÊNCIA ENTRE OS ADOLESCENTES}

Embora seja de conhecimento que a violência nas relações de intimidade entre os adolescentes ocorre, poucos estudos foram realizados no Brasil sobre esta temática, sendo mais abordada internacionalmente o de Minayo, Assis e Njaine (2011).

Quanto aos tipos de violência, predomina a violência verbal (Minayo, Assis, Njaine, 2011; Muñoz-Rivas et al, 2007).

Em estudo realizado na Austrália por Murphy e Smith (2010) evidenciou-se outra forma de violência que também ocorre nas relações de intimidade entre os adolescentes - a violência psicológica - neste caso motivada pelo ciúme, assim como encontrado por Fernándes-Fuertes e Fuertes (2010) na Espanha.

Em pesquisa desenvolvida por Brancaglioni e Fonseca (2016), onde foram pesquisados 111 adolescentes de escolas técnicas ou de ensino superior no município de Curitiba, constatouse que a violência verbal emocional também foi a mais perpetrada pelos participantes, em $90,1 \%$ dos casos.

As violências física e sexual também foram relatadas em estudos como os de O'Leary et al. (2008) e Muñoz- Rivas et al. (2007).

A partir dos estudos citados, pode-se afirmar que a violência nas relações de intimidade entre adolescentes é perpetrada porque 
existem na sociedade posições e construtos ideológicos que ratificam a assimetria de poder entre homens e mulheres. A violência ocorre porque a garota adolescente é vista como estando em posição inferior ao agressor (Gessner, Fonseca, Oliveira, 2014).

Estas e outras questões precisam ser levadas em conta quando está em cena a violência entre ou contra os adolescentes. Uma das estratégias utilizadas pelo Ministério da Saúde para o manejo de situações como a violência é a implantação das Redes de Atenção à Saúde.

\subsection{REDES DE ATENÇÃO À SAÚdE E O CONCEITO DE LINHA DE CUIDADO}

A partir do processo de descentralização, que se caracteriza como uma diretriz do Sistema Único de Saúde (SUS), foi feita a regionalização dos serviços de saúde, bem como dos recursos. O processo se inicia com uma pactuação entre os gestores das ações a serem ofertadas a população (Gryschek et al., 2014).

Outro importante aspecto da regionalização das ações em saúde, e posterior encaminhamento para criação das Redes de Atenção à Saúde (RAS), dentro do SUS, foi a necessidade de colocar a Atenção Primária como reguladora do sistema, contribuindo para a garantia da integralidade do cuidado.

A integralidade é outra diretriz do SUS importante para efetivação da Política Nacional de Humanização (Junges, Barbiani, 2012). A Política Nacional de humanização visa:

\footnotetext{
"ofertar um atendimento de qualidade, articulando avanços tecnológicos com acolhimento, com melhoria dos ambientes de cuidado e das condições de trabalho dos profissionais" (Brasil, 2004, p. 6).
}

Com a intenção de reorganizar a atenção prestada e consolidar o SUS, em 2011, o Ministério da Saúde publicou o 
decreto 7.508 que, entre outras determinações, reiterava o conceito de Redes de Atenção à Saúde (RAS) como:

$$
\begin{aligned}
& \text { "conjunto de ações e serviços de saúde } \\
& \text { articulados em níveis de complexidade crescente, } \\
& \text { com a finalidade de garantir a integralidade da } \\
& \text { assistência à saúde" (Brasil, 2011). }
\end{aligned}
$$

Desde sua implementação, o Ministério da saúde vem priorizando as seguintes RAS:

- Rede Cegonha - RC: Atenção Obstétrica e Neonatal;

- Rede de Atenção às Urgências e Emergências - RUE: linhas de cuidado prioritárias: I.A.M., A.V.C., Traumas (Acidentes de Trânsito) e Violência Doméstica;

- Rede da Atenção Psicossocial: Enfrentamento do Álcool, Crack e outras drogas;

- Rede de Cuidados à Pessoa com deficiência: reabilitação integrada, articulada e efetiva para atender pessoas com demandas decorrentes de deficiência temporária ou permanente; progressiva, regressiva, ou estável; intermitente e contínua;

- Rede de Atenção à Saúde das Pessoas com Doenças Crônicas: linhas de cuidado prioritárias: Câncer de Mama e do Colo de Útero, Doenças Respiratórias Crônicas, Hipertensão, Diabetes Mellitus, Obesidade e Sobrepeso.

No estabelecido pelas RAS, a linha de cuidado é caracterizada como uma ferramenta de microgestão e pode ser definida como um conjunto de saberes, tecnologias e recursos, necessários dentro de um sistema, para enfrentar de maneira satisfatória agravos, riscos ou condições específicas, de forma articulada entre os diferentes pontos de atenção do SUS (São Paulo, 2010).

A linha de cuidado pode ser apresentada como uma forma de ordenação do fluxo dos usuários dentro dos diferentes pontos de atenção. No sistema de Atenção à Saúde é imprescindível que esta 
ordenação do fluxo e que o sistema de regulação sejam eficazes para garantir a qualidade a assistência (Dubow et al., 2014).

Nas Redes de Atenção à Saúde, a linha de cuidado contribui para sistematização dos fluxos, auxiliando a organização das ações dentro dos serviços (Marinho et al., 2011). Com o delineamento do caminho percorrido pelo usuário diante da demanda a ser enfrentada na linha de cuidado, esta se torna uma importante ferramenta de atenção e também gerencial no processo de cuidado a ser estabelecido (Magalhães Júnior, Oliveira, 2006). A linha de cuidado pode ser utilizada como ferramenta nos diferentes pontos de atenção, inclusive localmente, nas UBSs para reorganização de fluxos assistenciais e de gestão.(São Paulo, 2010)

Diante da vivência da pesquisadora na atuação como Enfermeira da Família e gestora de UBS no município de Guarulhos e buscando qualificar as práticas que existem na cidade para a prevenção e enfrentamento da violência de gênero entre os adolescentes, surgiram os seguintes questionamentos:

- Os profissionais têm conhecimento de políticas públicas que os orientam para a prevenção e enfrentamento da violência entre os adolescentes nas relações de intimidade?

- Quais as diretrizes do município para o cuidado dos adolescentes envolvidos nesse tipo de violência, dentro da lógica das Redes de Atenção à Saúde (RAS)?

- Quais elementos estão contidos nas Políticas de Saúde do Município que podem fornecer diretrizes para a elaboração de uma linha de cuidado para prevenção e enfrentamento da violência nas relações de intimidade entre os adolescentes?

- Quais as concepções e os conhecimentos de profissionais de saúde acerca das práticas para prevenção e enfrentamento desse tipo de violência em Guarulhos? 


\section{OBJETIVOS}

\section{Gerais}

1. Obter subsídios para a construção de uma linha de cuidado para prevenção e enfrentamento da violência nas relações de intimidade entre adolescentes;

2. Construir uma linha de cuidado para prevenção e enfrentamento da violência nas relações de intimidade entre adolescentes.

\section{Específicos}

1. Identificar concepções de políticas públicas existentes para o cuidado da população adolescente no município de Guarulhos;

2. Verificar as concepções e os conhecimentos de profissionais de saúde acerca das práticas para prevenção e enfrentamento desse tipo de violência existentes em Guarulhos;

3. Desenhar uma linha de cuidado para prevenção da violência entre os adolescentes nas relações de intimidade, baseada nas políticas públicas existentes no Município de Guarulhos e nas concepções dos profissionais acerca do fenômeno, para utilização dos profissionais de saúde na Atenção Básica. 


\section{METODOLOGIA}

\subsection{REFERENCIAL TÉORICO - METODOLÓGICO}

\subsubsection{Adolescência}

De acordo com a Organização Mundial da Saúde (OMS), a adolescência é definida de maneira cronológica, como o período compreendido entre os 10 e os 19 anos (WHO, 1986). O estatuto da criança e do adolescente (ECA), no Brasil, define adolescência como a faixa etária compreendida entre os 12 e os 18 anos, sendo em casos excepcionais estendido aos 21 anos (Brasil, 1990). O estabelecimento de limites etários se dá prioritariamente para fins estatísticos, pois não se pode definir esta fase do ciclo de vida tão somente pela idade. Para o Ministério da Saúde, os adolescentes são sujeitos de direito e devem ser prioridade na implementação das políticas públicas de saúde (Brasil, 2010).

A adolescência é um conceito relativamente novo, incorporado aos estudos no século XX, uma vez que antes disso, não havia definição de transição entre infância e a idade adulta (Matos, Féres-Carneiro, Jablonski, 2005).

A partir dos estudos que definiram adolescência podemos dizer que se trata de uma fase do ciclo de vida humano onde o indivíduo passa por intensas transformações, não só de ordem puramente biológica, mas também mudanças psico-sócio-culturais importantes, que se consolidam nas relações que ele estabelece com a família, comunidade e sociedade em que vive, influenciado e influenciando esse meio, que garantirá a construção da sua personalidade na vida adulta (Neto et al., 2007).

É importante ressaltar, assim como afirmam Oliveira e Egry, (1997), que o conceito de adolescência é definido de acordo com a sociedade na qual o indivíduo está inserido. Diferentes sociedades, independente das mudanças biológicas que ocorrem nesta fase, 
caracterizam a adolescência de maneiras distintas, de acordo com os valores e características de vida e produção existentes.

$\mathrm{Na}$ atual sociedade brasileira, inserida no modo de produção capitalista, há de se tentar desmistificar concepções que colocam a adolescência simplesmente como transição entre infância e idade adulta. Os adolescentes estão inseridos na família e na comunidade, portando a cultura e os valores da sociedade atual, logo, ao prestar assistência, é imprescindível tentar reconhecer as formas particulares de vivência da adolescência (Soares, Avila, Salvetti, 2000).

Desta maneira, neste estudo, a adolescência será tratada como uma fase específica do ciclo de vida humana, que possui características que devem ser respeitadas e entendidas, dentro das formas de produção e reprodução social vigentes na sociedade brasileira. Além desse recorte, concebe-se ainda que os adolescentes se desenvolvam em meio às formas de construção da masculinidade e da feminilidade que determinam suas identidades e as questões de gênero que vivenciam.

\subsubsection{Violência e violência nas relações de intimidade entre adolescentes}

Os envolvimentos afetivos entre os adolescentes vêm sofrendo mudanças ao longo do tempo, sendo as concepções de sexualidade, amor e casamento diretamente influenciadas pelo contexto politico, religioso e cultural no qual este jovem está inserido (Matos, Féres-Carneiro, Jablonski, 2005).

Os adolescentes brasileiros vivem em uma sociedade de ambiguidades e têm que se adaptar a ela. De um lado, há atitudes e comportamentos conservadores e, de outro, o novo e o estrangeiro são cultuados. Com a aceleração do tempo e a quebra das barreiras geográficas e psicossociais através da tecnologia, as relações tendem a ser mais fluidas (Justo, 2005). 
No que tange aos relacionamentos afetivos de intimidade, na atualidade, podem ser reconhecidas diferentes maneiras de relacionamento entre os adolescentes, que são consequências da inserção destes indivíduos na sociedade. Em estudo realizado por Oliveira et al. (2007) são descritas três formas de relacionamento afetivo entre os adolescentes: o pegar, o ficar e o namorar.

O "pegar" é a forma mais livre de relacionamento que se baseia na espontaneidade, falta de compromisso formalizado e onde o interesse físico é predominante (Oliveira et al, 2007).

O "ficar" pode representar um desejo ou simplesmente uma forma superficial de relacionamento incentivado pelo seu ciclo de amizades. Mesmo sendo permitido à mulher tomar a iniciativa, ainda é considerado por alguns um ato vulgar mostrando que mesmo com todas as conquistas das mulheres, algumas concepções conservadoras ainda estão vigentes na sociedade (Silva, 2002).

O ficar é a forma de relacionamento intermediária entre o namoro e o "pegar", que se inicia de maneira espontânea e sem compromisso, mas que pode levar a uma regularidade e resultar em namoro. Já namorar sugere um ato contínuo e repetitivo do "ficar", assumindo um compromisso perante o ciclo de amizades, a família e a sociedade (Oliveira et al., 2007).

Mesmo modificando as formas de relacionamento, os adolescentes ainda revelam atitudes e comportamentos tradicionalistas no que diz respeito à mulher e à sua posição nos relacionamentos. Em relação à virgindade, por exemplo, aos homens ainda é permitido o livre exercício da sexualidade, ao contrário das mulheres, que devem se manter recatadas e intocadas (Matos, Féres-Carneiro, Jablonski, 2005).

Nos casos em que há discordâncias entre os pares, estas atitudes e comportamentos podem gerar conflitos e situações de violência entre os adolescentes nas suas relações de intimidade. 
A partir da Teoria da Determinação Social do processo Saúde-Doença, pode-se entender a violência nas relações de intimidade entre os adolescentes como um fenômeno social, constituídas a partir dos modos de produção e reprodução social aos que os adolescentes estão inseridos (Gessner, 2013).

Para Fonseca, Egry e Bertolozzi (2006), a Teoria da Determinação do Processo Saúde Doença prega que:

\begin{abstract}
"O processo saúde-doença, por sua vez, não pode ser pré-determinado ou obedecer a padrões préestabelecidos de normalidade, mas é determinado historicamente pela forma de inserção social do ser humano na sociedade ou, em última instância, pela forma como ele se relaciona com a natureza e com os demais homens. Não pode existir fora da sociedade." (Fonseca, Egry e Bertolozzi, 2006, p.5)
\end{abstract}

A prevenção e o enfrentamento da violência nas relações de intimidade entre os adolescentes é primordial para as ações de saúde nesta população e a definição das concepções e sua inserção no contexto histórico e social deve assumir especial importância para o entendimento e manejo desta situação (Oliveira et al., 2016).

\title{
3.2 CENÁRIO DE ESTUDO
}

O estudo foi realizado no município de Guarulhos, um dos 39 municípios localizados na região metropolitana de São Paulo, com população em 2014, segundo dados do IBGE de 1.312.197 habitantes em 2014, e extensão territorial de $318,675 \mathrm{~km}^{2}$ e densidade demográfica de $3.834,51 \mathrm{hab} / \mathrm{km}^{2}$, sendo a $12^{\mathrm{a}}$ cidade mais populosa do país. 
Figura 1 - Mapa da Região Metropolitana de São Paulo

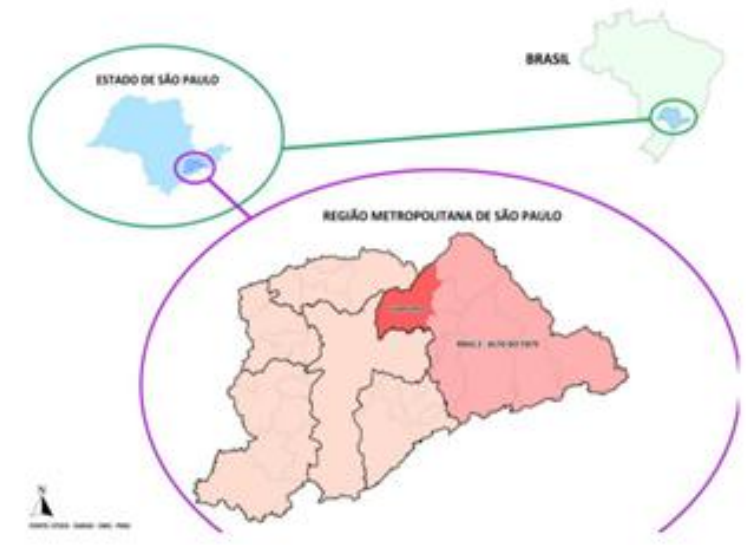

Fonte: Guarulhos. Secretaria da Saúde. Política Municipal de Práticas Integrativas e Complementares em Saúde. 2014

Com a cidade de São Paulo, Guarulhos faz divisa com os seguintes distritos: ao norte Tremembé, Jaçanã, Vila Medeiros e Vila Maria; e, a leste com Cangaiba, Vila Jacuí, Ermelino Matarazzo, São Miguel Paulista e Jardim Helena, estes últimos, historicamente marcados pela segregação territorial e exclusão social, e que são próximos ao distrito Água Chata onde foi realizada a pesquisa (Guarulhos, 2014).

Nas últimas décadas, o município acolheu uma grande quantidade de migrantes internos, especialmente da região nordeste, em busca de oportunidades de emprego e moradia. A ocupação errática levou à construção de uma cidade caracterizada por fortes demandas sociais e uma grande expansão demográfica (Guarulhos, 2014).

"De acordo com os dados do PIB Municipal 2010, divulgados pelo IBGE, o Produto Interno Bruto (PIB) de Guarulhos em 2010 alcançou a marca de $\mathrm{R} \$ 37,1$ bilhões, situando-se na $8^{\text {a }}$ posição do ranking nacional, e em $2^{\circ}$ entre municípios paulistas, sendo o $4^{\circ}$ maior PIB municipal da região sudeste, além de ser o maior município não capital do País, Guarulhos é atualmente o 8o maior PIB industrial do país e $010^{\circ}$ de Serviços. O 
município possui o segundo maior Parque Industrial do Estado de São Paulo, destacando-se as indústrias ligadas ao ramo metal mecânico, eletroeletrônico, químicofarmacêutico, alimentícia e têxtil. O comércio e o setor de serviços, especialmente os ramos de Transportes e Logística, são também atividades com significativa presença na cidade, em função da localização estratégica do município e da presença do Aeroporto Internacional de Guarulhos." (Guarulhos, 2014, p. 9)

No gráfico que se segue pode-se observar a expansão populacional que ocorreu na cidade de Guarulhos após a década de 50, quando ocorreu a abertura nacional da economia para instalação das grandes empresas internacionais do município. Verifica-se também a progressão geométrica do crescimento e consegue-se entender as dificuldades para o crescimento organizado da população dentro do território, o que acabou ocasionando formas de viver, morar e trabalhar inadequadas dentro da cidade (Guarulhos, 2014).

Gráfico 1 - Crescimento populacional município de Guarulhos de 1920 a 2010

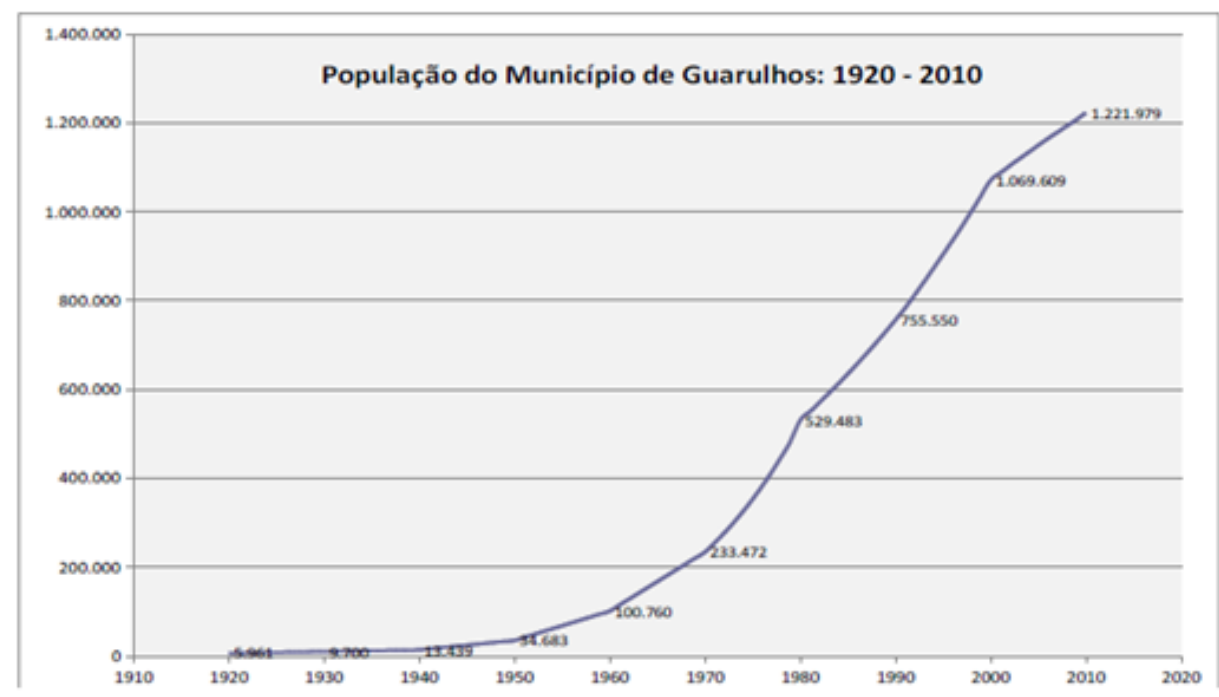

Fonte: Guarulhos. Secretaria da Saúde. Curso Introdutório Atenção Básica. 2014 
Mesmo sendo sede de empresas multinacionais, que movimentam o capital da cidade, o município possui $4,4 \%$ de sua população vivendo em extrema pobreza sendo a renda per capita de Guarulhos em 2010 de $R \$ 784,00$, inferior a média do Estado de São Paulo que foi de $R \$ 1.080,00$. Possui um quinto de sua população com rendimentos inferiores a meio salário mínimo. (Guarulhos, 2014). No Estado de São Paulo esta porcentagem é de $14,7 \%$ da população, como demonstrado no gráfico abaixo:

Gráfico 2 - Comparação entre a renda do município de Guarulhos, a Região Metropolitana de São Paulo e o Estado de São Paulo

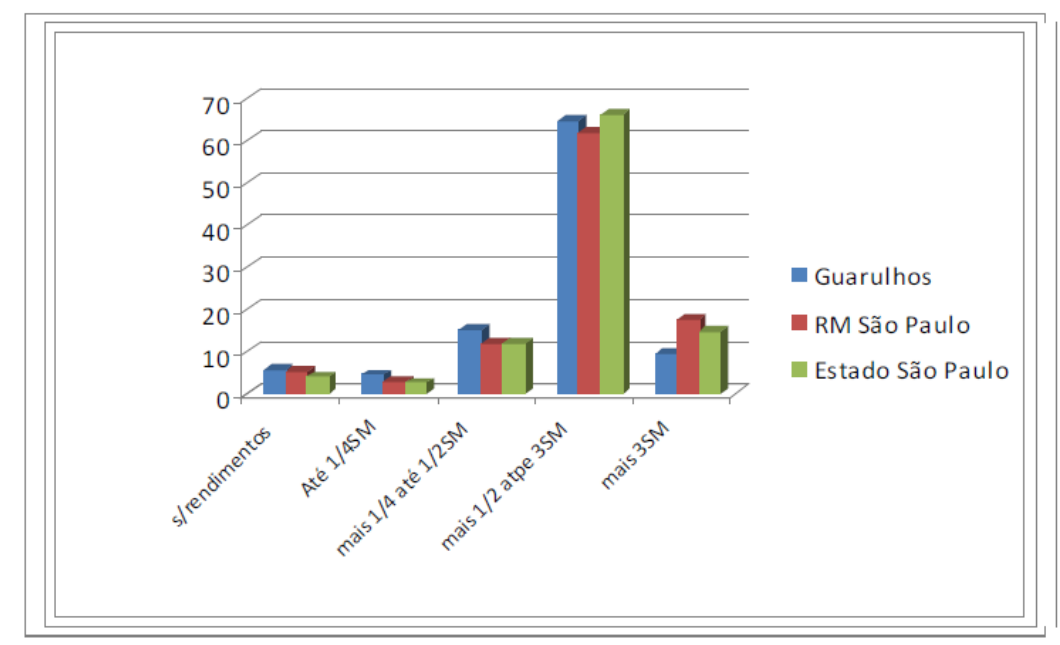

Fonte: Guarulhos. Secretaria da Saúde. Política Municipal de Práticas Integrativas e Complementares em Saúde. 2014

Seguindo a lógica das Redes de atenção à Saúde, o Estado de São Paulo foi dividido em 17 Redes Regionalizadas de atenção à Saúde (RRAS). Guarulhos compõe a RRAS - 2 - Alto Tietê, junto com os municípios de Arujá; Biritiba Mirim; Ferraz de Vasconcelos; Guararema; Itaquaquecetuba; Mogi das Cruzes; Poá; Salesópolis; Santa Isabel e Suzano, constituindo $45 \%$ da população desta RRAS. (Guarulhos, 2014)

A Secretaria da Saúde de Guarulhos está organizada em quatro Regiões de Saúde Intramunicipais, a saber: Região I - Centro, 
Região II - Cantareira, Região III - São João/Bonsucesso e Região IV Pimentas/Cumbica como demonstrado na figura abaixo:

Figura 2 - Mapa das Regiões de Saúde do Município de Guarulhos

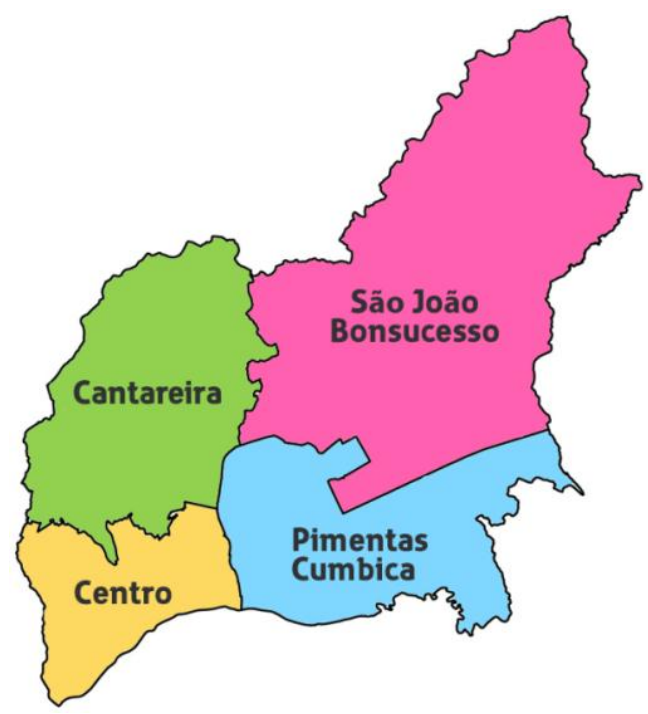

Fonte: Guarulhos. Secretaria da Saúde. Política Municipal de Práticas Integrativas e Complementares em Saúde. 2014

Estas regiões estão subdivididas em 18 Distritos de Saúde. A rede de atenção primária à saúde é composta por 67 unidades básicas de saúde, sendo 37 com Estratégia Saúde da Família (com cobertura de aproximadamente $22 \%$ população) e 30 no modelo tradicional.

Além da Rede de Atenção Básica, o município conta também com 49 equipamentos de média e alta complexidade onde são também desenvolvidas algumas ações de promoção da saúde.

$\mathrm{Na}$ Região Pimentas-Cumbica a distribuição da moradia, assim como relatado no Plano Local de Habitação e de Interesse Social de Guarulhos em 2011 caracteriza-se por:

"urbanização periférica, com exiguidade de áreas verdes e institucionais, descontinuidade do sistema viário, lotes de tamanho reduzido, frequentemente subdivididos em mais de uma família residente" (Guarulhos, 2011, p.48) 
Está localizado na divisa dos municípios de Arujá, Itaquaquecetuba e São Paulo, possui histórico de crescimento populacional na última década, que não acompanhou o crescimento da infraestrutura, fazendo com que a população migre para esses outros municípios em busca de serviços.

A região de Saúde IV Pimentas/Cumbica compreende 4 distritos de Saúde, Distrito Jurema, Distrito Cumbica, Distrito Pimentas e Distrito Água Chata. O Distrito Água tem 61.754 habitantes, correspondendo a $18,3 \%$ da população total da Região de saúde, possuindo como equipamentos de saúde 5 UBS com estratégia Saúde da Família, sendo compostas por 13 equipes, e 1 UBS tradicional.

Atendem as unidades do distrito, 2 Núcleos de Apoio à Saúde da Família (NASF Aracília e NASF Nova Cidade) e um Núcleo de apoio a atenção básica (NAAB Jandaia). O distrito possui 16 escolas pactuadas no PSE, com 9855 crianças e adolescentes acompanhados.

\subsection{TIPO DE ESTUDO}

Trata-se de uma pesquisa descritiva, exploratória, de abordagem qualitativa.

A pesquisa qualitativa busca favorecer a compreensão de um fenômeno social de determinada realidade, trabalhando com universo de significados, que não podem ser transformados em variáveis como as da pesquisa quantitativa (Minayo, 2001).

O estudo é qualitativo porque busca compreender o atendimento aos adolescentes vitimas de violência nas relações de intimidade no município de Guarulhos, bem como as politicas públicas existentes. Sua finalidade é construir a linha de cuidado.

Segundo Triviños (1987), a pesquisa descritiva busca descrever os fatos ou fenômenos de uma determinada realidade, 
como as politicas públicas existentes em Guarulhos que contemplassem o objetivo proposto.

A pesquisa é exploratória porque verificou junto aos participantes suas concepções e práticas realizadas no manejo da violência na cidade Guarulhos. Essas informações puderam trazer maior familiaridade ao tema e fornecer subsídios para construir linha de cuidado (Gil, 2007).

\subsection{PRESSUPOSTOS}

Diante das questões da pesquisa e de seus objetivos foram considerados os seguintes pressupostos:

- As políticas públicas voltadas ao adolescente no município de Guarulhos não abordam as questões de violência nas relações de intimidade

- Os profissionais de saúde não possuem respaldo de políticas públicas para o manejo e prevenção da violência nas relações de intimidade entre os adolescentes

- As concepções dos profissionais envolvidos no enfrentamento da violência nas relações de intimidade entre adolescentes oscilam entre ideologias que tanto superam como ratificam o fenômeno

- A construção de uma linha de cuidado para prevenção da violência nas relações de intimidade entre os adolescentes auxiliaria a implementação das RAS.

- É necessário um incremento de ações para qualificar profissionais de saúde a fim de prevenir e enfrentar a violência nas relações de intimidade entre adolescentes na perspectiva de gênero, baseado nas políticas públicas municipais. 


\subsection{PROCEDIMENTOS METODOLÓGICOS}

\subsubsection{Coleta e organização dos dados}

A obtenção dos dados primários foi feita através de questionário auto-preenchido (Apêndices 1 e 2) composto por um relato de caso de violência nas relações de intimidade entre adolescentes, seguido de questões que objetivaram levantar posicionamentos e sentimentos acerca do relato descrito.

Os critérios de seleção utilizados para escolha dos participantes foram: serem profissionais da saúde que atendem os casos de demanda espontânea e atuem profissionalmente nas unidades pertencentes ao Distrito Água Chata, integrante do Departamento da Região de Saúde IV, do município de Guarulhos. Este distrito foi escolhido devido à facilidade de acesso da pesquisadora aos sujeitos de pesquisa, uma vez que estou na gerência de uma das UBSs participantes, bem como por sediar as discussões do encontro "Guarulhos, cidade que protege", com temática voltada para a prevenção da violência na juventude.

Os questionários foram aplicados nos locais de trabalho dos profissionais, em data e horários acordados entre o participante, a pesquisadora e o gerente da unidade. Este gerente havia sido anteriormente informado sobre a coleta de dados que se iniciaria na sua unidade pelo Departamento da Região de Saúde.

Depois de respondidos os questionários, os dados quantitativos foram inseridos em um banco de dados criado pela pesquisadora em Excel. Os dados qualitativos foram tratados através do software WEBQDA. Em seguida, procedeu-se à análise por categorias.

A utilização do software WEBQDA favoreceu a organização dos dados e sua sistematização para posterior análise e conclusão. 
"O WebQDA (Web Qualitative Data Analysis) é um software de análises de dados qualitativos num ambiente colaborativo e distribuído. O WebQDA é um software destinado à investigação em ciências humanas e sociais e proporciona inúmeras vantagens na análise de dados qualitativos. Este é o primeiro software de análise de dados não numéricos e não estruturados num ambiente colaborativo e distribuído com base na internet." (Souza, Costa, Moreira, 2011, p. 19).

Foi também realizada uma busca documental referente às políticas públicas que tratam dos adolescentes na base de dados disponibilizada no site da Prefeitura Municipal de Guarulhos (www.guarulhos.sp.gov.br). Nesta base de dados foi possível consultar leis, decretos, projetos de Lei, autógrafos e mensagens de veto vigentes no município. Para isso, é permitido o refinamento da pesquisa de acordo com tipo de informação, o número, o ano de publicação ou alguma palavra que faça parte da ementa da norma legal ou da proposição desejada.

Além da pesquisa na base de dados do município, foi realizada consulta junto aos órgãos existentes em Guarulhos que tratam das temáticas da pesquisa. Na Secretaria da Saúde, foram consultado os Grupos Condutores das Rede de Atenção as Doenças Crônicas e de Atenção Psicossocial, que tratam da temática da violência. Além da Secretaria da Saúde foram consultados, a Coordenadoria da Mulher, a Coordenadoria da Juventude e o Conselho Municipal do Adolescente.

Foram então selecionadas as políticas que tratavam dos temas propostos nos objetivos e os dados organizados em tabela criada pela pesquisadora. Posteriormente, foi feita a análise dos aspectos contidos nas políticas que se referiam à prevenção e ao enfrentamento da violência entre os adolescentes. 


\subsubsection{Análise dos dados}

A análise dos dados, obtidos na entrevista e no levantamento documental, foi realizada utilizando-se orientações da análise de conteúdo, que de acordo com Bardin (2009):

\footnotetext{
"trata-se de um método que procura conhecer aquilo que está por trás das palavras sobre as quais se debruça, é a busca de outras realidades através das mensagens".
}

Para análise de conteúdo, procedeu-se de acordo com as três fases abaixo descritas (Bardin, 2009):

- Pré-análise: consiste na organização dos dados, iniciando a sistematização das ideias principais;

- Exploração do material: fase de decodificação das falas obtidas nas entrevistas;

- Tratamento dos resultados obtidos e interpretação: análise e interpretação do pesquisador de acordo com as categorias que forem eleitas para esse fim.

Para Minayo (2001), a análise de conteúdo busca uma leitura compreensiva dos dados, incluindo sua classificação e organização, favorecendo a análise de acordo com as categorias elencadas pelo pesquisador para verificação dos pressupostos e descoberta do que está além do manifesto.

Portanto, após inserção dos dados no Software WEBQDA, foi realizada análise do conteúdo e separado em macro categorias a partir do referencial teórico. Buscando responder aos objetivos da pesquisa, as categorias de análise utilizadas foram:

- Concepção sobre Adolescente e Adolescência

- Concepção sobre Violência e Tipo de violência 
- Concepção sobre Violência entre adolescente nas relações de intimidade

- Práticas de prevenção e enfrentamento da violência 
ASPECTOS ÉTICOS 


\section{ASPECTOS ÉTICOS}

A pesquisa foi submetida ao Comitê de Ética da Escola de Enfermagem, respeitando os requisitos da resolução 466/2012 do Conselho Nacional de Saúde sob no CAAE 51283515.6.0000.5392. Foi também submetida à aprovação do Secretário da Saúde do Município de Guarulhos, como preconizado pelo município de Guarulhos para realização de pesquisas e intervenções junto aos servidores e usuários do sistema de saúde local.

Após provação dos órgãos competentes e antes da coleta de dados, os participantes assinaram o Termo de Consentimento Livre e Esclarecido apresentado pela pesquisadora. (Apêndice 3) 
RESULTADOS 


\section{RESULTADOS}

\subsection{POLÍTICAS PÚBLICAS PARA A ADOLESCÊNCIA EM GUARULHOS}

O conceito de políticas públicas é interdisciplinar e amplo, e podem ser encontradas diferentes definições para ele (Souza, 2006; Silva e Bassi, 2012). Para o presente estudo utilizaremos a definição de Políticas Públicas como sendo:

[...] um processo de decisão política que se
materializa em objetivos com resultados
esperáveis, normalmente vinculados à
transformação de uma dada realidade, com
vetores distintos, e que envolvem: a) técnicos
estatais e não governamentais, burocratas e
políticos (tomadores de decisão); b) atores
distintos (com "recursos de poder" assimétricos),
cenários e conjunturas (por vezes voláteis); c)
capacidade e viabilidade de o Estado disponibilizar
recursos orçamentários, humanos, legais e
logísticos; d) mecanismos de mensuração dos
resultados. (Fonseca, 2013, p. 405).

A partir desta definição foram encontradas no município de Guarulhos três políticas que tratam da saúde ou do cuidado com o adolescente e que auxiliam o manejo da violência que ocorre nas relações de intimidade entre eles.

\subsection{1 - Programa Saúde na Escola (PSE)}

O Programa Saúde na Escola é um direcionamento dos Ministério da Saúde e da Educação para o atendimento dos escolares, com repasse de verbas aos municípios. Guarulhos fez a adesão ao PSE em 2011.

Instituído em 2007, pelo Ministério da Saúde, através do decreto presidencial no 6.286, o Programa Saúde na Escola (PSE) trata de uma política de intersetorialidade entre saúde e educação, a fim de promover saúde e educação integral para crianças, jovens e adultos (Brasil, 2007). No caderno de orientações aos gestores, o Ministério da Saúde (Brasil, 2015), justifica a efetivação do PSE: 
"As práticas em Educação e Saúde devem considerar os diversos contextos com o objetivo de realizar construções compartilhadas de saberes sustentado pelas histórias individuais e coletivas, com papéis sociais distintos - professores, educandos, merendeiras, porteiros, pais, mães, avós, entre outros sujeitos-produzindo aprendizagens significativas e ratificando uma ética inclusiva. Desse modo, dimensionando a participação ativa de diversos interlocutores/sujeitos em práticas cotidianas, é possível vislumbrar uma escola que forma cidadãos críticos e informados com habilidades para agir em defesa da vida e de sua qualidade, e que devem ser compreendidos pelas equipes de Atenção Básica em suas estratégias de cuidado." (Brasil, 2015, p. 7)

O PSE tem como finalidade contribuir para o fortalecimento de ações integradas de saúde e educação que auxiliem crianças, jovens e adultos, inseridos em uma determinada comunidade, a transformar sua realidade tanto de saúde como de vulnerabilidade, a fim de melhorar a qualidade de vida da população. Para que isso ocorra se faz necessário:

\footnotetext{
"compreender que o espaço escolar não deve ser utilizado para consultas médicas, com o objetivo da medicalização ou de diagnóstico clínicopsíquico dos fracassos do processo ensinoaprendizagem, mas apenas para detecção de sinais e sintomas de agravos em saúde, por sua objetividade e ganho de escala em ambiente coletivo" (Brasil, 2015, p. 8)
}

As ações desenvolvidas pela atenção básica devem garantir a promoção da saúde e não somente atingir o plano biológico da atenção ao indivíduo. Devem ser propostas ações que estejam dentro do projeto político pedagógico da escola, mas que sejam passíveis de transformação com o apoio da equipe da atenção básica, seguindo as seguintes diretrizes:

I. Descentralização e respeito à autonomia federativa.

II. Integração e articulação das redes públicas de ensino e de 
saúde, por meio da junção das ações do Sistema Único de Saúde (SUS) às ações das redes de educação pública, de forma a ampliar o alcance e o impacto de suas ações relativas aos educandos e suas famílias, otimizando a utilização dos espaços, dos equipamentos e dos recursos disponíveis.

III. Territorialidade, respeitando as realidades e as diversidades existentes no espaço sob responsabilidade compartilhada.

IV. Interdisciplinaridade e intersetorialidade, permitindo a progressiva ampliação da troca de saberes entre diferentes profissões e a articulação intersetorial das ações executadas pelos sistemas de Saúde e de Educação, com vistas à atenção integral à saúde de crianças e adolescentes.

V. Integralidade, tratando a saúde e educação integrais como parte de uma formação ampla para a cidadania e o usufruto pleno dos direitos humanos, fortalecendo o enfrentamento das vulnerabilidades, no campo da Saúde, que possam comprometer o pleno desenvolvimento escolar.

VI. Cuidado ao longo do tempo, atuando, efetivamente, no acompanhamento compartilhado durante o desenvolvimento dos educandos, prevendo a reorientação dos serviços de Saúde para além de suas responsabilidades técnicas no atendimento clínico, o que envolve promover a saúde e a cultura da paz; favorecer a prevenção de agravos; avaliar sinais e sintomas de alterações; prestar atenção básica e integral aos educandos e à comunidade.

VII. Controle social: promover a articulação de saberes, a participação dos educandos, pais, comunidade escolar e sociedade em geral na construção e controle social das políticas públicas da Saúde e Educação.

VIII. Monitoramento e avaliação permanentes: promover a comunicação, encaminhamento e resolutividade entre escolas e Unidades de Saúde, assegurando as ações de atenção e cuidado sobre a condição de saúde dos estudantes e 
informando as que forem realizadas nos sistemas de monitoramento.

IX. Avaliar o impacto das ações junto aos educandos participantes do PSE (Brasil, 2015).

Além das diretrizes, o PSE é composto também por componentes que tratam de divisões das ações que devem ser realizadas para que os objetivos propostos pelo programa sejam alcançados, são eles:

- Componente I - avaliação das condições de saúde (clínica e psicossocial)

- Componente II - promoção da saúde e prevenção de agravos, onde são utilizadas linhas de cuidado principais para o desenvolvimento de ações.

- Componente III - formação dos atores envolvidos (seja da educação ou da saúde) para o cumprimento das diferentes metas do programa (Brasil, 2011).

Dentro do componente II, a quinta linha de ação aborda a promoção da cultura de paz e prevenção das violências, utilizando estratégias para enfrentamento dos seus diversos tipos, inclusive versando sobre as questões de gênero.

\subsection{2 - Política Municipal de Promoção à Saúde (PMPS)}

Em 2014, o Município de Guarulhos publicou sua Política Municipal de Promoção à Saúde (PMPS). No que tange à prevenção da violência tem por objetivo estimular a adoção de modos de viver não violentos e o desenvolvimento de uma cultura de paz no município. Para isso, foram propostas diversas ações para garantir o cumprimento dessa meta:

- Fortalecer o núcleo de prevenção às violências e promoção da saúde; 
- Promover a sensibilização, qualificação e atualização dos gestores e profissionais de saúde e rede intersetorial na identificação, manejo e encaminhamento adequado de situações das diversas violências;

- Estimular a articulação intersetorial no território visando à redução, mapeamento e intervenções nas situações de abuso, exploração e turismo sexual;

- Reforçar a importância do preenchimento da ficha de notificação de violência doméstica, sexual e outras violências, e demais instrumentos de registro;

- Incentivar o desenvolvimento de um Plano Municipal de Prevenção das Violências, com monitoramento e avaliação do seu desenvolvimento, mediante a realização de coleta, sistematização, análise e disseminação de informações;

- Reforçar a importância dos meios de notificação de denúncias de maus tratos aos animais, levando em conta a associação entre a crueldade com animais e as outras expressões de violência familiar;

- Implantar e estimular e fortalecer ações de: combate ao trabalho infantil; combate ao trabalho escravo; acolhimento adequado aos imigrantes; combate à pedofilia; combate ao uso impróprio da imagem da mulher, da criança e do adolescente; combate à prostituição infantil; combate ao tráfico de pessoas; combate à violência contra os animais (Guarulhos, 2014).

Para viabilizar a implementação dessas ações foram criadas parcerias entre os setores da saúde, educação e assistência social. 


\subsection{3 - Programa Saúde na Adolescência}

Criado em 2011, este programa tem por objetivos:

I - desenvolver ações prevenção para estimular o adolescente quanto à necessidade de preservar a sua saúde física, psicológica e social;

II - estimular o adolescente nas práticas educativas e participativas; III - estimular o envolvimento do adolescente, dos seus familiares, da comunidade em geral nas ações a serem desenvolvidas e implementadas (Guarulhos, 2011).

A concepção de adolescente deste programa restringe-se apenas a faixa etária, sendo considerados adolescentes as pessoas de 12 a 18 anos, e tem caráter assistencialista, sendo suas áreas de atuação as que se seguem:

I - assistência social, quando serão analisados as condições e problemas de natureza sócio-econômica do adolescente;

II - enfermagem, quando será feito um levantamento inicial de dados de orientação sobre aspectos preventivos e educativos para adolescentes;

III - psicológico, propiciando ao adolescente oportunidades de autoconhecimento acerca de suas potencialidades e seu conflitos;

IV - atendimento clínico ou pediátrico e odontológico, com o intuito de prevenir, diagnosticar, tratar e recuperar a saúde do adolescente; V - ações educativas, que serão desenvolvidas de acordo com as principais diretrizes da Organização Mundial da Saúde.

\subsubsection{Legislação encontrada}

As políticas públicas, para serem implementadas, necessitam redundar em legislação correspondente. Foi realizada uma busca na base de dados do município de Guarulhos, através do site da prefeitura, e consulta as secretarias da Saúde, da Assistência Social, 
da Educação e as coordenadorias da Mulher e da Juventude, e a legislação encontrada para auxiliar a efetivação das Políticas Públicas voltadas para o enfrentamento da violência nas relações de intimidade entre adolescentes existentes no município de Guarulhos estão organizadas nos quadros a seguir:

Quadro 1 - Decretos municipais sobre adolescentes vigentes em Guarulhos

\begin{tabular}{|c|c|}
\hline Decretos e Leis & Finalidade \\
\hline $\begin{array}{c}\text { Decreto } \mathrm{n}^{\circ} 22855 \text { de } \\
07 / 10 / 04\end{array}$ & $\begin{array}{l}\text { Criar o Comitê Municipal de } \\
\text { Enfrentamento á Violência Doméstica e } \\
\text { Sexual contra Crianças e Adolescentes }\end{array}$ \\
\hline $\begin{array}{c}\text { Decreto } \mathrm{n}^{\circ} 23475 \text { de } \\
20 / 10 / 05\end{array}$ & $\begin{array}{l}\text { Criar CEDAP - Centro de Diagnóstico, } \\
\text { Ação e Prevenção Contra Violência } \\
\text { Doméstica e Sexual de Crianças e } \\
\text { Adolescentes de Guarulhos }\end{array}$ \\
\hline $\begin{array}{c}\text { Decreto } n^{\circ} 29756 \text { de } \\
02 / 03 / 12\end{array}$ & $\begin{array}{l}\text { Instituir a Comissão Intersetorial para } \\
\text { Elaboração, Implementação e } \\
\text { Acompanhamento do Plano Municipal de } \\
\text { Atendimento a Crianças e Adolescentes }\end{array}$ \\
\hline
\end{tabular}

Ainda sobre a temática foram encontradas 12 leis vigentes no município, descritas no quadro abaixo:

Quadro 2 - Leis municipais sobre adolescentes vigentes em Guarulhos

\begin{tabular}{|c|c|}
\hline Nome & Finalidade \\
\hline Lei $n^{\circ} 6160$ de & $\begin{array}{c}\text { Programa de Incentivo às Atividades } \\
\text { Artísticas e Integração Social para } \\
\text { crianças e adolescentes }\end{array}$ \\
\hline
\end{tabular}




\begin{tabular}{|c|c|}
\hline Lei $n^{\circ} 6583$ de 19/11/09 & $\begin{array}{l}\text { Dispõe sobre criação do Programa } \\
\text { Família Acolhedora para crianças e } \\
\text { adolescentes em situação de risco } \\
\text { social e dá outras } \\
\text { providências. }\end{array}$ \\
\hline Lei $n^{\circ} 6584$ de 19/11/09 & $\begin{array}{l}\text { Cria o Orçamento Criança e } \\
\text { Adolescente no Município de } \\
\text { Guarulhos, como instrumento de } \\
\text { controle social e fiscalização do } \\
\text { orçamento público na área da criança } \\
\text { e do adolescente }\end{array}$ \\
\hline Lei $n^{\circ} 6587$ de 19/11/09 & $\begin{array}{l}\text { Dispõe sobre a criação do Disque } \\
\text { Criança e Adolescente, destinado a } \\
\text { atender denúncias de maus tratos, } \\
\text { abandono ou } \\
\text { qualquer outra forma de violência } \\
\text { contra crianças e adolescentes }\end{array}$ \\
\hline Lei $n^{\circ} 6635$ de 11/01/10 & $\begin{array}{c}\text { Cria o Cadastro Municipal de Registro } \\
\text { de Casos de Violência Contra } \\
\text { Crianças e Adolescentes }\end{array}$ \\
\hline $\begin{array}{l}\text { Lei } n^{\circ} 6665 \text { de } \\
\qquad 19 / 04 / 10\end{array}$ & $\begin{array}{l}\text { Institui Programa de Casas de Apoio, } \\
\text { destinadas ao atendimento de } \\
\text { adolescentes grávidas, nas } \\
\text { comunidades carentes }\end{array}$ \\
\hline Lei $n^{\circ} 6747$ de $03 / 11 / 10$ & $\begin{array}{c}\text { Dispõe sobre a oficialização da Rede } \\
\text { Guarulhense de não violência à } \\
\text { mulher }\end{array}$ \\
\hline Lei $n^{\circ} 6766$ de 22/11/10 & $\begin{array}{l}\text { Dispõe sobre a obrigatoriedade dos } \\
\text { estabelecimentos citados a fixarem em } \\
\text { lugar visível cartaz alusivo aos crimes } \\
\text { cometidos contra a criança e ao } \\
\text { adolescente, com número telefônico } \\
\text { da Secretaria Especial de Direitos } \\
\text { Humanos (SEDH) do Governo Federal }\end{array}$ \\
\hline Lei $n^{\circ} 6953$ de 21/11/11 & $\begin{array}{l}\text { Criação do Observatório de Proteção } \\
\text { Integral à Infância e Adolescência }\end{array}$ \\
\hline Lei $n^{\circ} 7425$ de 11/12/15 & $\begin{array}{l}\text { Implanta o Conselho Municipal da } \\
\text { Juventude, institui o Fundo Municipal }\end{array}$ \\
\hline
\end{tabular}




\begin{tabular}{|c|c|}
\hline & da Juventude \\
\hline \multirow{2}{*}{ Lei $n^{\circ} 7463$ de 14/03/16 } & Obriga o Poder Executivo a afixar \\
& cartazes contendo o artigo $4^{\circ}$ do ECA \\
& em Hospitais, UBS's, Creches, e \\
& Escolas Municipais \\
\hline
\end{tabular}

\subsection{CONCEPÇÕES E CONHECIMENTOS DE PROFISSIONAIS DE SAÚDE ACERCA DAS PRÁTICAS PARA PREVENÇÃO E ENFRENTAMENTO DA VIOLÊNCIA ENTRE ADOLESCENTES}

\subsubsection{Caracterização da amostra}

Os questionários foram aplicados a 17 profissionais da atenção básica, responsáveis pelo acolhimento nas unidades de saúde, sendo nove enfermeiras, dois educadores físicos, duas nutricionistas, uma assistente social, uma fisioterapeuta, uma psicóloga e uma terapeuta ocupacional.

Quanto ao sexo, eram 15 do sexo feminino e 2 do sexo masculino, com idades que variavam entre 27 e 53 anos. A respeito do tempo de formação 4 tinham até 5 anos de formação, 7 entre cinco e 10 anos e 6 se formaram há mais de 10 anos. Na Prefeitura Municipal de Guarulhos 10 tinham menos de 5 anos de contratação e 7 tinham de 5 a 10 anos.

Dentre os entrevistados, 12 eram casados, três estavam em união estável e dois solteiros. No que diz respeito à formação complementar, 12 profissionais possuem esta formação em diferentes áreas como apresentado no quadro a seguir: 
Tabela 2 - Distribuição dos participantes de acordo com a formação complementar

\begin{tabular}{l|l}
\hline Formação Complementar & № profissionais \\
\hline Administração hospitalar & 1 \\
\hline Apoio à Saúde da Família & 3 \\
\hline Atendimento nutricional & 1 \\
\hline Enfermagem obstétrica & 1 \\
\hline Enfermagem do trabalho & 1 \\
\hline Fisiologia do exercício & 1 \\
\hline Gestão em Saúde & 1 \\
\hline Nutrição humana & 1 \\
\hline Psicopedagogia & 1 \\
\hline Saúde coletiva & 1 \\
\hline Saúde da família & 4 \\
\hline Vigilância Sanitária & 1 \\
\hline Terapia nutricional & 1 \\
\hline Total ${ }^{*}$ & 18 \\
\hline
\end{tabular}

*Um dos participantes, possuía mais de uma formação complementar

Quando perguntados sobre experiência no atendimento de adolescentes, somente um profissional respondeu que não tinha. As experiências eram diversificadas em termos de tipo de atendimento sendo que, a mais citada foi o acolhimento, por 7 dos participantes. Referiram experiência nas consultas e dos grupos, 6 profissionais. No pré natal, 3 deles já tiveram contato com adolescentes. $O$ Programa Saúde na Escola foi mencionado por 2 sujeitos, assim como a coleta de papanicolaou e 1 deles relatou a experiência junto ao teatro do oprimido.

A experiência com vítimas de violência foi relatada por 10 dos participantes sendo o acolhimento e as consultas o momento mais mencionado e a violência física e sexual a mais abordada nos atendimentos. 


\subsubsection{Dados qualitativos}

A partir da inserção dos dados no Software WebQDA, foram extraídas categorias empíricas. O quadro a seguir apresenta as categorias e os temas que lhe correspondem:

Quadro 3 - Categorias de análise e temas abordados

\begin{tabular}{|c|c|}
\hline Categoria & Temas abordados \\
\hline \multirow[t]{11}{*}{$\begin{array}{l}\text { Concepções sobre adolescente } \\
\text { e adolescência }\end{array}$} & $\begin{array}{l}\text { Insegurança e imaturidade do } \\
\text { adolescente }\end{array}$ \\
\hline & Vulnerabilidade do adolescente \\
\hline & Reprodução contexto familiar \\
\hline & Falta de suporte social \\
\hline & Fase de conflitos \\
\hline & Fase de descobertas \\
\hline & Instabilidade emocional \\
\hline & Baixa autoestima \\
\hline & Educação sexual \\
\hline & Saúde do adolescente \\
\hline & Medo da solidão \\
\hline \multirow{5}{*}{$\begin{array}{l}\text { Concepções violência e tipos de } \\
\text { violência }\end{array}$} & Violência de gênero \\
\hline & $\begin{array}{l}\text { Violência nas relações de } \\
\text { intimidade }\end{array}$ \\
\hline & Estrutura familiar \\
\hline & Enfrentamento das vítimas \\
\hline & Impunidade \\
\hline \multirow{6}{*}{$\begin{array}{l}\text { Concepção sobre violência entre } \\
\text { adolescente nas relações de } \\
\text { intimidade. }\end{array}$} & Fragilidade da relação \\
\hline & Prejuízo vida social \\
\hline & Apoio familiar \\
\hline & Posição da vítima \\
\hline & Banalidade da violência \\
\hline & $\begin{array}{l}\text { Saúde na exposição à vida } \\
\text { sexual }\end{array}$ \\
\hline
\end{tabular}




\begin{tabular}{|l|l|}
\hline Práticas de prevenção e & Desconstrução de conceitos \\
enfrentamento da violência & Grupos na unidade \\
\hline & Informação sobre legislação \\
\hline & "Guarulhos, cidade que protege" \\
\hline & $\begin{array}{l}\text { Escassez de serviços no } \\
\text { município }\end{array}$ \\
\hline & Programa Saúde na Escola \\
\hline & Serviços de apoio à vítima \\
\hline & Acolhimento \\
\hline & Notificação da violência \\
\hline & NASF / NAAB \\
\hline & Adolescente deve procurar ajuda \\
\hline & Projeto de vida \\
\hline
\end{tabular}

Na categoria concepções sobre adolescente e adolescência, os participantes relataram a adolescência como uma fase de transição, conflituosa e vulnerável.

"A adolescência é uma fase em que o indivíduo busca a "marca" pela identidade, tem curiosidades, dificuldade de lidar com os sentimentos, são contrários às ideias apresentadas, intensificam ações e desejos. Sendo assim, apresentam uma vulnerabilidade a álcool e drogas, sexualidade e DSTs," (NNC05)

"A fase da adolescência é permeada por uma série de conflitos e descobertas, a busca da edificação da identidade e a vulnerabilidade de seguir "aquilo que meus iguais" pregam é bastante presente nesta fase" (NA02)

"Pouca reserva interna para enfrentamento de problemas" (N01)

Referindo-se a categoria violência e tipos de violência observou-se que os participantes atribuíam a violência a diferentes fatores, prevalecendo a Teoria da multicausalidade.

"Anabela é uma adolescente insegura, imatura que tem medo de 
ficar sozinha" (N03)

"Falta de estrutura familiar / Baixa autoestima / Pouca reserva interna para enfrentamento de problemas / Falta de suporte social" (NNC04)

"Problemas de âmbito familiar- Ricardo agressivo com a dinâmica familiar perturbada pela dependência química do pai e deficiência do irmão." (N04)

Alguns participantes trouxeram elementos da Teoria da Determinação do Processo Saúde Doença na categoria concepção sobre violência entre adolescente nas relações de intimidade à luz de gênero.

"Penso que este comportamento é resultado da cultura machista que herdamos do nosso passado distante e continuamos reproduzindo" (NNC01)

"E essa desigualdade também é reproduzida nas relações de gênero, onde o homem muitas vezes talvez por sua força física ou pelo poder econômico ou até mesmo por encontrar fundamentação religiosa acaba reproduzindo um comportamento de superioridade frente à mulher, que por muitas vezes também reproduz esse comportamento." (NNC02)

$\mathrm{Na}$ categoria práticas de prevenção e enfrentamento da violência de gênero, os participantes reconheceram que a promoção a saúde do adolescente é um campo importante, porém que ainda não está consolidado nas ações diárias da equipe como nos exemplos abaixo:

"Sinto também que o excesso de trabalho dificulta muitas vezes o acolhimento com escuta qualificada de adolescentes" (N01)

"Para saúde acessar essa faixa etária é muito difícil, quando é ofertado ações no sentido de orientação em diversos âmbitos, não 
há grande adesão. Grupos de adolescentes nas unidades básicas são difíceis de ter duração, pois eles não permanecem por muito tempo." (NA01)

As principais formas de prevenção e enfrentamento das situações de violência de gênero praticadas pelos profissionais em sua atenção ao adolescente foram citadas de acordo com as frases abaixo:

\section{- Ações desenvolvidas no Programa Saúde na Escola (PSE)}

“Hoje no município de Guarulhos são desenvolvidas algumas ações em conjunto com o Programa Saúde na Escola com palestras educativas para adolescentes, com temas de sexualidade, DSTs, cultura de paz, prevenção de álcool e drogas" (N03)

"O Programa Saúde na Escola (PSE) que em um dos eixos trabalha a questão de violência" (NNC05)

- Encontro "Guarulhos, cidade que protege"

"e reuniões com profissionais da saúde e educação juntos como "Guarulhos Cidade que Protege". (N03)

"O espaço do grupo Guarulhos: Cidade que protege, para discussão de casos de modo multidisciplinar" (J01)

- Acolhimento na Unidade Básica de Saúde

"Ao atender a paciente na UBS, a enfermeira deverá acolher a mesma, entendendo todos os pontos da história" (NA03)

\section{- Grupos na Unidade Básica de Saúde}

"Se a unidade dispor de saúde da família deve encaminhar/discutir o caso com a equipe de apoio, em ações em grupo e individuais" (NA03) 
"Busca de estratégias, tais como grupo direcionado aos adolescentes que pode ser pactuado entre a $E A B+N A S F+$ Equipamentos de Assistência Social" (NNC05)

"na unidade temos um grupo de adolescentes onde são abordados temas relacionados entre outros com sexualidade, respeito" (N02)

- Compartilhar caso com os Núcleos de Apoio (NASF / NAAB)

"O caso pode ser discutido com o Núcleo de Apoio à Saúde da Família para ampliar a discussão; assistente social poderá realizar uma abordagem compartilhada com a AB para a orientação sobre a situação e saber um pouco mais sobre estrutura familiar" (NNC05)

"temos nas UBSs (na maioria) a equipe NASF, onde a mulher receberá o apoio psicológico e acompanhamento" (NC01)

\section{Realização de Projeto de Vida}

"orientá-la sobre escolhas, responsabilidade" (NA03)

"Penso que esta adolescente tem que ver se é isso mesmo que ela quer para a vida dela, ser controlada, manipulada, sem privacidade $e$ violentada. A enfermeira Joana poderia fazer um acolhimento no sentido de mostrar a ela o quanto ela é jovem e que tem muitas coisas para serem vividas e conquistadas" (N03)

"Trazer reflexão sobre onde relacionamento pode levá-la." (NNC04) 
Os profissionais também relataram as dificuldades encontradas para realizar as ações de prevenção e enfrentamento da violência entre os adolescentes:

"Reuniões e capacitações onde se discute e define os fluxos de atendimento nos casos de violência, porém é frágil o apoio intersetorial" (P01)

"Sensação de incapacidade, muito difícil para a UBS resolver sem o devido apoio intersetorial" (P01)

"Desconheço alguma ação ou equipamento que possa prevenir o problema apresentado" (NA03)

A partir dos resultados obtidos com a coleta dos dados foi elaborada a Linha de Cuidado que se segue para utilização na Atenção Básica no município de Guarulhos. 
LINHA DE CUIDADO PARA PREVENÇÃO E ENFRENTAMENTO DE VIOLÊNCIA NAS RELAÇÕES DE INTIMIDADE ENTRE OS ADOLESCENTES

Kátia Darbello da Silva

Rosa Maria Godoy Serpa da Fonseca

Guarulhos 


\section{TÓPICOS ABORDADOS}

INTRODUÇÃO

CONCEITOS BÁSICOS

Rede de Atenção à Saúde e Linha de Cuidado

Tipos de violência

Adolescente e Adolescência

Violência nas relações de intimidade entre os adolescentes

ESTRATÉGIAS DE PREVNÇÃO

Programa Saúde na Escola

"Guarulhos, cidade que protege"

\section{ESTRATÉGIAS DE ENFRENTAMENTO}

Identificação da violência

Papel da Atenção Primária à Saúde no combate à violência

Acolhimento

Núcleo de Apoio à Saúde da Família (NASF)

Grupos na unidade

Construção do Projeto de Vida na adolescência

FLUXOGRAMA DE ATENÇÃO A VIOLÊNCIA NAS RELAÇÕES DE INTIMIDADE NO MUNICÍPIO DE GUARULHOS

\section{CONSIDERAÇÕES FINAIS}

\section{REFERÊNCIAS}

ANEXO A - Serviços de Apoio Intersetorial

ANEXO B - Legislação vigente em Guarulhos sobre adolescente

ANEXO C - Fluxograma de atenção à vítima de violência sexual no município de Guarulhos 


\section{APRESENTAÇÃO}

Esta Linha de Cuidado é produto da dissertação de Mestrado Profissional apresentada pela autora sob a orientação da $\operatorname{Prof}^{-a}$ Dr $^{\text {a }}$ Rosa Maria Godoy Serpa da Fonseca ao Programa de Mestrado Profissional do Departamento de Enfermagem em Saúde Coletiva da Escola de Enfermagem da Universidade de São Paulo (EEUSP) para obtenção do título de Mestre em Ciências na Atenção Primária à Saúde.

A elaboração desta Linha de Cuidado foi baseada num estudo realizado em duas importantes fontes de dados:

1. Análise documental das Políticas Públicas vigentes no Município de Guarulhos para prevenção e enfrentamento da violência do adolescente;

2. Análise das concepções, conhecimentos e práticas de profissionais de saúde acerca da prevenção e enfrentamento desse tipo de violência.

Participaram profissionais atuantes no Distrito Água Chata da Região de Saúde IV - Pimentas/ Cumbica, do município de Guarulhos.

Após a análise dos dados obtidos na pesquisa citada, foi elaborada a presente Linha de Cuidado.

Ela tem por objetivo auxiliar na assistência prestada a essa população, a partir das práticas já realizadas no município. E subsidiar as ações com conceitos fundamentais para a qualificação dos profissionais envolvidos, melhorando o cuidado oferecido as adolescentes vítimas de violência nas relações de intimidade.

Entende-se aqui que o subsídio conceitual apresentado servirá de base para as ações específicas na prevenção e enfrentamento da violência de gênero nas relações de intimidade 
entre os adolescentes. Porém ela pode e deve ser utilizada como exemplo para construções de novas linhas de cuidado para a assistência a violência, devendo-se então aplicar a ela o novo arcabouço conceitual e prático necessário para diferentes as abordagens. 


\section{INTRODUÇÃO}

Em 2012, o Instituto Brasileiro de geografia e estatística (IBGE), publicou a Pesquisa Nacional de Saúde do Escolar, realizada com 109.104 estudantes do $9^{\circ}$ ano do ensino fundamental em escolas de todo o território nacional. O objetivo foi conhecer e dimensionar os diversos fatores de risco e proteção relacionados à saúde desta população. A publicação evidencia a importância de o tema violência ser tratado quando se pensa na saúde da população adolescente. Dos estudantes pesquisados, 10,6\% declararam que haviam sofrido recentemente agressão física por adultos da família. Com relação ao envolvimento em brigas com armas, 7,3\% deles se envolveram em brigas com arma branca e $6,4 \%$ com arma de fogo. As agressões verbais sofridas no ambiente escolar também foram pesquisadas e $35,4 \%$ dos alunos declararam já se terem se sentido humilhados com as provocações dos colegas de escola. Outros $20,8 \%$ declararam já ter humilhado e magoado algum de seus colegas (Brasil, 2013).

Dados de 2011 obtidos do SINAN (Sistema de Informação de Agravos de Notificação) revelam que foram atendidos no SUS e geraram notificações 73.633 pessoas vítimas de algum tipo de violência. Destas, 11.600 eram jovens de 10 a 19 anos e a maioria, cerca de 65\%, do sexo feminino (Waiselfisz, 2012).

No Município de Guarulhos (SP), em 2012, o número de jovens de 10 a 19 era de 335.540 pessoas. Em 2010, as causas externas correspondiam à primeira causa de morte entre estes jovens. A taxa de homicídios, nesta população, foi de 40,8/100 mil habitantes. Comparada com a taxa de homicídios para a população em geral que foi de 21,5/100 mil habitantes em 2012.(Guarulhos, 2014). 
Dentre as diferentes formas de violência existentes, na adolescência, também pode ser encontrada a violência nas relações de intimidade.

O adolescente brasileiro vive em uma sociedade de ambiguidades e tem que se adaptar a ela. De um lado, há atitudes e comportamentos conservadores e, de outro, o novo e o estrangeiro são cultuados. Com a aceleração do tempo e a quebra das barreiras geográficas e psicossociais através da tecnologia, as relações tendem a ser mais fluidas (Justo, 2005).

$\mathrm{Na}$ atualidade, podem ser reconhecidas diferentes maneiras de relacionamento entre os adolescentes. Essas relações são determinadas pela maneira como se organiza a sociedade e a inserção destes indivíduos nela. Mesmo numa época em que as formas de relacionamento estão se modificando muito rapidamente, os adolescentes ainda revelam atitudes e comportamentos tradicionalistas no que diz respeito à mulher e à sua posição nos relacionamentos. Em relação à virgindade, por exemplo, aos homens ainda é permitido o livre exercício da sexualidade, ao contrário das mulheres, que devem se manter recatadas e intocadas (Matos, Féres-Carneiro, Jablonski, 2005).

Estas atitudes e comportamentos podem gerar conflitos e situações de violência entre os adolescentes nas suas relações de intimidade. Embora seja de conhecimento geral que isto ocorre, poucos estudos foram realizados no Brasil sobre esta temática, sendo mais abordada internacionalmente (Minayo, Assis, Njaine, 2011). Estas e outras questões precisam ser levadas em conta quando está em cena a violência entre ou contra os adolescentes. 


\section{CONCEITOS BÁSICOS}

Esta Linha de Cuidado baseia-se nos seguintes conceitos chaves para a prevenção e enfrentamento da violência nas relações de intimidade entre adolescentes.

\section{REDE DE ATENCÃ̃O À SAÚDE E LINHA DE CUIDADO}

A partir do processo de descentralização, que se caracteriza como uma diretriz do Sistema Único de Saúde (SUS), foi feita a regionalização dos serviços de saúde, bem como dos recursos. O processo se inicia com uma pactuação entre os gestores das ações a serem ofertadas a população (Gryschek et al., 2014).

Outro importante aspecto da regionalização das ações em saúde, e posterior encaminhamento para criação das Redes de Atenção à Saúde (RAS), dentro do SUS, foi a necessidade de colocar a Atenção Primária como reguladora do sistema, contribuindo para a garantia da integralidade do cuidado. A integralidade é outra diretriz do SUS importante para efetivação da Política Nacional de Humanização (Junges, Barbiani, 2012).

No estabelecido pelas RAS, a linha de cuidado é caracterizada como uma ferramenta de microgestão e pode ser definida como um conjunto de saberes, tecnologias e recursos, necessários dentro de um sistema, para enfrentar de maneira satisfatória agravos, riscos ou condições específicas, de forma articulada entre os diferentes pontos de atenção do SUS (São Paulo, 2010).

A linha de cuidado pode ser apresentada como uma forma de ordenação do fluxo dos usuários dentro dos diferentes pontos de atenção. No sistema de Atenção à Saúde é imprescindível que esta ordenação do fluxo e que o sistema de regulação sejam eficazes para garantir a qualidade a assistência (Dubow et al., 2014). 
Figura 1 - Elementos constituintes de uma linha de cuidado

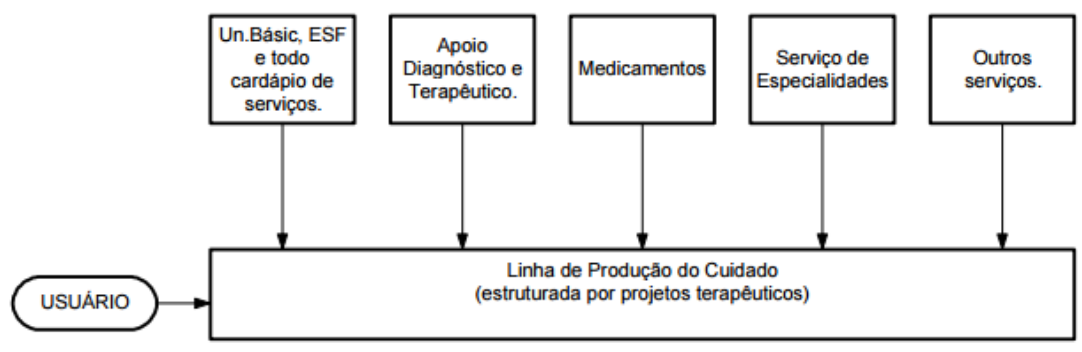

Fonte: Franco TB, Junior HMM. Integralidade na assistência à Saúde: A organização das linhas do cuidado. In: Mehry et al. O Trabalho em Saúde: olhando e experienciando o SUS no cotidiano. São Paulo: Hucitec; 2004.

Com o delineamento do caminho percorrido pelo usuário diante da demanda a ser enfrentada na linha de cuidado, esta se torna uma importante ferramenta de atenção e também gerencial no processo de cuidado a ser estabelecido (Magalhães Júnior, Oliveira, 2006). 


\section{TIPOS DE VIOLÊNCIA}

A violência pode ser perpetrada de diferentes formas, assim como demonstrado na figura abaixo:

Figura 2 - Classificação do tipo de violência de acordo com a natureza.

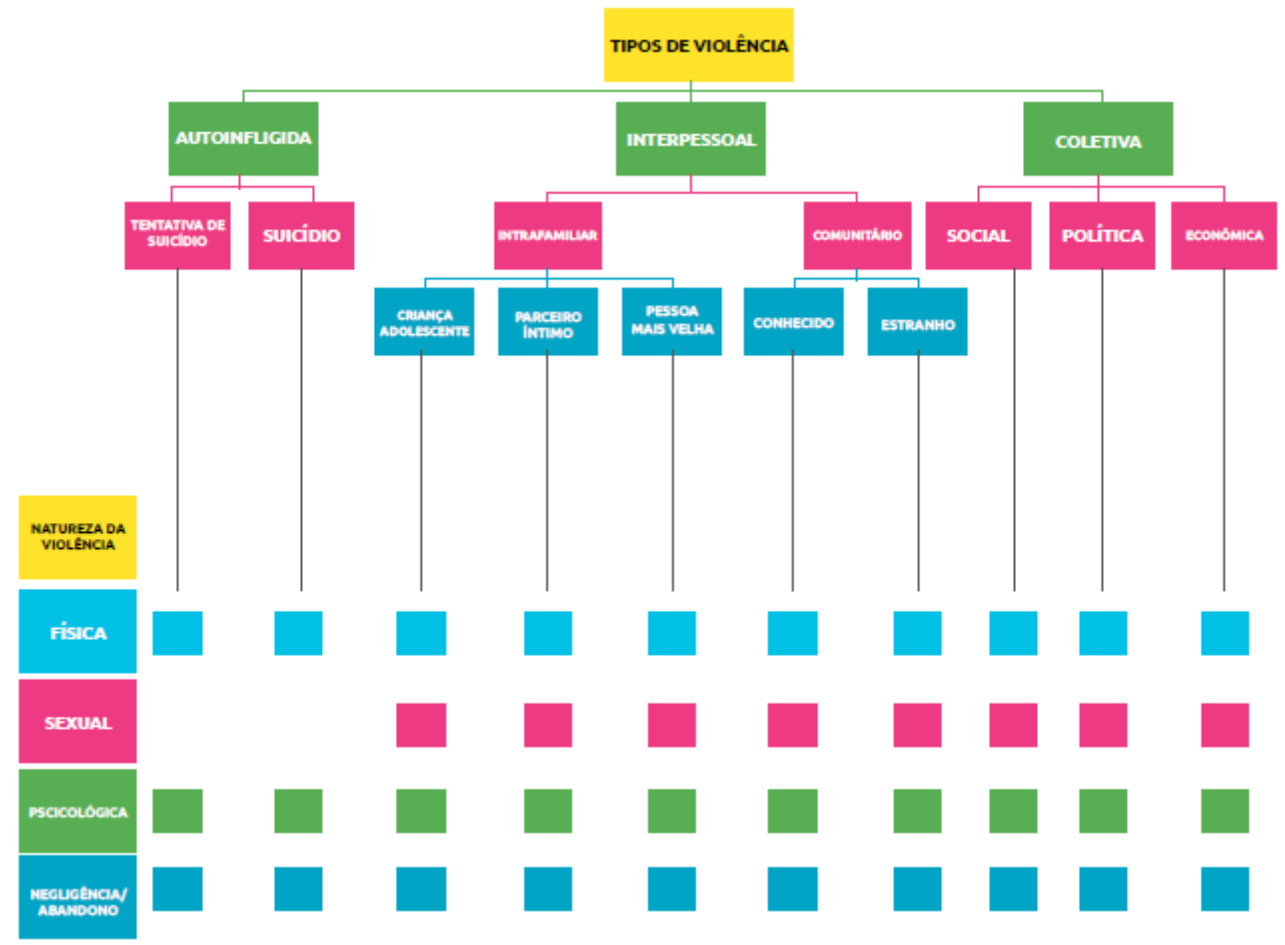

Fonte: Krug EG, Mercy JA, Dahlberg LL, Zwi AB. The world report on violence and health. The lancet. 2002;360 (9339):1083-8

Desta maneira é verificado que a violência sofrida por parceiro intimo pode ser de todas as naturezas, ou seja, física, sexual, psicológica e negligência / abandono e cabe ao profissional saber reconhecer e oferecer o cuidado adequado. 


\section{ADOLESCENTE E ADOLESCÊNCIA}

Para a Organização Mundial da Saúde (OMS), a adolescência é definida de maneira cronológica, como o período compreendido entre os 10 e os 19 anos (WHO, 1986). O Estatuto da Criança e do Adolescente (ECA), no Brasil, define adolescência como a faixa etária compreendida entre os 12 e os 18 anos, sendo em casos excepcionais estendido aos 21 anos (Brasil, 1990). O estabelecimento de limites etários se dá prioritariamente para fins estatísticos, pois não se pode definir esta fase do ciclo de vida tão somente pela idade. Para o Ministério da Saúde, os adolescentes são sujeitos de direito e devem ser prioridade na implementação das políticas públicas de saúde (Brasil, 2010).

A adolescência é um conceito relativamente novo, incorporado aos estudos no século XX, uma vez que antes disso, não havia definição de transição entre infância e a idade adulta (Matos, Féres-Carneiro, Jablonski, 2005).

Trata-se de uma fase do ciclo de vida humano onde o indivíduo passa por intensas transformações, não só de ordem biológica, mas também psico-sócio-culturais importantes.

É importante ressaltar que o conceito de adolescência é definido de acordo com a sociedade na qual o indivíduo está inserido. Diferentes sociedades, independente da mudança biológica que ocorre nesta fase, caracterizam a adolescência de uma maneira diferente, de acordo com os valores e características de vida e produção existentes (Oliveira, Egry, 1997).

$\mathrm{Na}$ atual sociedade, inserida no modo de produção capitalista, há de se tentar desmistificar concepções que colocam a adolescência simplesmente como transição entre infância e idade adulta. Os adolescentes estão inseridos na família e na comunidade, com a cultura e valores da sociedade atual, portanto, ao prestar assistência, é imprescindível tentar reconhecer as formas 
particulares de vivência da adolescência (Soares, Avila, Salvetti, 2000).

Um determinante que interfere no cuidado à saúde do adolescente é a concepção de que eles são seres incapazes e conflituosos. Para Oliveira e Lyra (2008), este pensamento tornase uma dificuldade na atenção a saúde do adolescente porque os profissionais não consideram esta população composta por sujeitos de direitos, por serem imaturos e irresponsáveis.

Esta concepção dificulta a horizontalidade das relações que é necessária no atendimento a essa população, buscando tornar o serviço de saúde atrativo às demandas que interessam ao adolescente e favorecem também sua adesão e vínculo ao sistema (Oliveira, Lyra, 2008). 
VIOLÊNCIA NAS RELACÕES DE INTIMIDADE ENTRE ADOLESCENTES

Os envolvimentos afetivos entre os adolescentes vêm sofrendo mudanças ao longo do tempo, sendo as concepções de sexualidade, amor e casamento diretamente influenciadas pelo contexto politico, religioso e cultural no qual este jovem está inserido. (Matos, Féres-Carneiro, Jablonski, 2005).

Os adolescentes brasileiros vivem em uma sociedade de ambiguidades e têm que se adaptar a ela. De um lado, há atitudes e comportamentos conservadores e, de outro, o novo e o estrangeiro são cultuados. Com a aceleração do tempo e a quebra das barreiras geográficas e psicossociais através da tecnologia, as relações tendem a ser mais fluidas (Justo, 2005).

No que tange aos relacionamentos afetivos de intimidade, na atualidade, podem ser reconhecidas diferentes maneiras de relacionamento entre os adolescentes, que são consequências da inserção destes indivíduos na sociedade.

Nos casos em que há discordâncias entre os pares, estas atitudes e comportamentos podem gerar conflitos e situações de violência entre os adolescentes nas suas relações de intimidade.

Diante disso, pode-se afirmar que a violência existente nas relações de intimidade entre adolescentes existe porque existem na sociedade posições e construtos ideológicos que ratificam a assimetria de poder entre homens e mulheres. A violência ocorre porque a garota adolescente é vista como estando em posição inferior ao agressor (Gessner, Fonseca, Oliveira, 2014).

Entender o adolescente como ser social, construído e transformado histórico, cultural e socialmente, permite aos profissionais compreender a dinâmica da adolescência. Implica 
compreender os adolescentes como seres transformadores da sociedade e de sua saúde, o que favorece o cuidado prestado. 


\section{ESTRATÉGIAS DE PREVENÇÃO}

No que tange a prevenção da violência nas relações de intimidade entre os adolescentes, podemos citar dois espaços importantes de atuação profissional que permitem discussões e ações sobre essa temática.

\section{PROGRAMA SAÚDE NA ESCOLA}

O Programa Saúde na Escola (PSE) é um direcionamento dos Ministério da Saúde e da Educação para o atendimento dos escolares, com repasse de verbas aos municípios. Guarulhos fez a adesão ao PSE em 2011.

Instituído em 2007, pelo Ministério da Saúde, através do decreto presidencial no 6.286, o Programa Saúde na Escola (PSE) trata de uma política de intersetorialidade entre saúde e educação, a fim de promover saúde e educação integral para crianças, jovens e adultos (Brasil, 2007).

O PSE tem como finalidade contribuir para o fortalecimento de ações integradas de saúde e educação que auxiliem crianças, jovens e adultos, inseridos em uma determinada comunidade, a transformar sua realidade tanto de saúde como de vulnerabilidade, a fim de melhorar a qualidade de vida da população.

As ações desenvolvidas pela atenção básica devem garantir a promoção da saúde e não somente atingir o plano biológico da atenção ao indivíduo. Devem ser propostas ações que estejam dentro do projeto político pedagógico da escola, mas que sejam passíveis de transformação com o apoio da equipe da atenção básica (Brasil, 2015).

O PSE possui componentes que tratam de divisões das ações que devem ser realizadas para que os objetivos propostos pelo programa sejam alcançados, sendo que em seu componente II, a 
quinta linha de ação preconiza trabalhar com os educandos sobre promoção de cultura de paz e prevenir violências.

Além disso, o componente III aborda a formação permanente de atores da saúde e da educação para garantir o cumprimento dos objetivos do Programa (Brasil, 2011).

Aplicações da Linha de Cuidado: É possível utilizar os conceitos abordados nesta Linha de Cuidado para realizar ações do componente II nas escolas, como rodas de conversas e grupos de educação em saúde com estudantes, fortalecendo as relações da equipe de atenção básica (EAB) com os adolescentes, abordando a temática da violência dentro dos outros temas e inserida no contexto de vida deles, favorecendo a reflexão.

O componente III preconiza a formação dos atores da educação e da saúde para o cuidado desta população e esta Linha de Cuidado é um material importante para isso. Portanto, algumas ações que a equipe de saúde realiza com os profissionais de educação podem utilizar este material como referência no manejo e discussão da violência nas relações de intimidade entre os adolescentes dentro da escola.

\section{“GUARULHOS, CIDADE QUE PROTEGE”}

Outro importante espaço de prevenção e discussão acerca desse tipo de violência instituído no município de Guarulhos são as reuniões do projeto "Guarulhos, cidade que protege".

Baseado na Política Municipal de Promoção à Saúde que versa sobre a prevenção da violência foi instituído um espaço de deliberação sobre este tema com o nome de "Guarulhos, cidade que protege".

Dentro do componente III do PSE (- formação dos atores envolvidos para o cumprimento das diferentes metas do programa), 
o município de Guarulhos articulou espaços de discussão sobre prevenção de violências, num programa denominado "Guarulhos cidade que protege".

São encontros interdisciplinares e intersetoriais, envolvendo profissionais e gestores da saúde, da educação, do Centro de Referência de Assistência Social (CRAS), Centro de Referência Especializado de Assistência Social (CREAS), do poder judiciário e da população para discussão e manejo, em rede, dos casos de violência ocorridos em determinada população.

Têm por objetivos:

* Mobilizar os atores locais: escolas, unidades básicas de saúde, centros de referência de assistência social, conselho tutelar, entre outros, para potencializar suas ações de prevenção e promoção no território;

* Construir um projeto piloto para o enfrentamento das violências contra crianças e adolescentes, visando tornar-se referência para o município (Medeiros, 2010).

Pode-se reconhecer que a união de um grupo multiprofissional e intersetorial para discussão em conjunto de casos para prevenção é um grande avanço nas políticas instituídas no município, pois a falta dessa organização é um dos dificultadores da equipe de saúde da família para o manejo das situações de violência (Bezerra, Monteiro, 2012).

Aplicação da Linha de Cuidado: Durante 0 ano são realizadas mensalmente reuniões do Projeto "Guarulhos, cidade que protege", e esta Linha de Cuidado pode embasar algumas discussões e atividades dessas reuniões. Aproveitando o caráter multiprofissional e intersetorial do encontro, os profissionais podem ser capacitados para o manejo da violência nas relações de intimidade entre os adolescentes, e ela pode servir para maior integração e resolutividade da rede municipal de combate à violência. 


\section{ESTRATÉGIAS DE ENFRENTAMENTO}

\section{IDENTIFICACÃO DA VIOLÊNCIA}

Para o manejo das situações de violência é importante que o profissional reconheça os sinais e sintomas mais frequentes e que podem ser apresentados pelas vítimas de violência, que vão além dos físicos e podem se manifestar nos adolescentes por:

- Mudanças de comportamento (como irritabilidade, apatia);

- Mudanças de humor (como choro e tristeza constantes);

- Distúrbios de alimentação;

- Tendência a solidão;

- Somatização (como alergias constantes);

- Tiques ou manias;

- Automutilação e tentiva de suicídio;

- Deficit de atenção e / ou hiperatividade;

- Comportamento de risco (como uso abusivo de drogas).

Sabendo disso, o profissional pode estar atento em diferentes momentos de contato com os adolescentes para intervir em uma situação de violência existente e que pode não ter sido verbalizada. (Brasil, 2010) 
PAPEL DA ATENCÃO PRIMÁRIA A SAÚdE NO COMBATE A VIOLÊNCIA

A organização dos Sistema Único de Saúde (SUS) a partir das Redes de Atenção à Saúde, surgiu, além de outros motivos, para fortalecer a atenção primária à saúde (APS).

A APS é entendida como o centro e a coordenadora do cuidado prestado a população, cabendo a ela direcionar e acompanhar os fluxos, uma vez que se entende que é ela que pode acompanhar o sujeito de forma integral e contínua, como estabelece o SUS (Barra, 2013).

Assumindo o papel principal de coordenadora do cuidado, a APS, além de assistir a integralidade do sujeito, consegue racionalizar os recursos e ações assumidos pelos outros níveis de atenção (Mendonça, 2007).

Aplicação da Linha de Cuidado: utilizando a Linha de Cuidado, pode-se estabelecer fluxos ordenados de atenção as vitimas de violência nas relações de intimidade entre adolescentes, e com isto, evitar desgastes nas relações com os usuários e facilitar a prática profissional a partir da coordenação das equipes de atenção básica.

\section{ACOLHIMENTO}

Caracterizado como o primeiro contato entre o profissional e a adolescente a fim de prestar atendimento integral as situações que a mesma trás ao serviço, tentando desta maneira se aproximar de sua condição e realizar o cuidado que ela veio buscar .

De acordo com a Política Nacional de Humanização, publicada em 2010 pelo MS, o acolhimento deve ser entendido como um momento de escuta qualificada e que é responsável pelo estabelecimento de vínculos entre o usuário e o profissional, que 
irão influenciar diretamente a eficiência e eficácia do atendimento prestado (Lima et al, 2007).

O acolhimento é o momento escolhido para as orientações sobre os diversos temas que envolvem a situação de violência, para a oferta dos serviços disponíveis, para a notificação e denúncia do caso e realização dos diferentes encaminhamentos propostos.

\section{NÚCLEO DE ATENCÃO À SAÚDE DA FAMÍLIA (NASF)}

O Sistema Único de Saúde (SUS) tem como uma de suas diretrizes o acesso à assistência, onde a atenção primária à saúde, materializada no modelo da estratégia saúde da família, tem papel regulador de fluxo, podendo garantir a equidade no acesso aos meios de saúde (Merhy, 1998).

Além disso, o SUS tem o papel de ordenador de recursos humanos na área de saúde o que implica retirar o foco das ações assistencialistas e entender que o cuidado deve conjugar ações de prevenção e promoção da saúde, além da cura e da reabilitação.

Todas estas ações exigem pluralidade de saberes e o trabalho em equipe interdisciplinar e multiprofissional, preferencialmente em rede (Ciuffo, Ribeiro, 2008). Uma das ferramentas utilizadas para o trabalho multidisciplinar e integral é o apoio matricial. Tem por objetivo ampliar a resolubilidade dos serviços através do apoio técnico oferecido por diferentes profissionais numa relação horizontal entre as especialidades (Campos, 1999).

Em 2010, foram criados os Núcleos de Apoio à Saúde da Família (NASF) e à Atenção Básica (NAAB), tendo como uma de suas diretrizes o fortalecimento das ações de Promoção da Saúde. Esses núcleos, assim como as Redes de Atenção à Saúde fazem parte de um processo transversal no desenvolvimento da promoção à saúde. 
Aplicações da Linha de Cuidado: Os conceitos, fluxos e informações estabelecidas nesta linha de cuidado auxiliam os profissionais da EAB e do NASF no manejo das situações de violência nas relações de intimidade entre os adolescentes, bem como ratificar práticas existentes, subsidiando a qualificação das ações e encaminhamentos dos casos.

\section{GRUPOS NA UNIDADE}

A realização de grupos de educação em saúde na unidade também pode ser considerada uma prática de enfrentamento da violência nas relações de intimidade entre os adolescentes quanto essa temática for abordada, pois esta estratégia favorece a interação entre os adolescentes e os profissionais.

É importante manter a concepção de que o adolescente é capaz de decidir sobre o que quer, que é sujeito de direitos e opiniões para garantir adesão a esse tipo de abordagem. Aproveitando esta oportunidade para incentivar sua tomada de decisão em relação à saúde e sua cidadania no processo educativo (Teixeira et al., 2014).

As temáticas abordadas devem partir do adolescente, utilizando metodologia participativa, proporcionando reflexão e diálogo, favorecendo a formação de vínculo entre o participante e o profissional (Oliveira, Ressel, 2010).

A realização dos grupos sobre violência na unidade, abordada a partir de temáticas sugeridas pelos adolescentes e com metodologias motivadoras contribuem para a mudança de comportamento e enfrentamento da violência, melhorando a qualidade de vida (Tavares et al., 2012). 


\section{CONSTRUCÃO DO PROJETO DE VIDA NA ADOLESCÊNCIA}

O projeto de vida pode ser definido como uma possibilidade de transformação do futuro através de representação social do contexto de inserção do adolescente, bem como da possibilidade de transformação desta realidade (Catão, 2001).

Durante a construção do Projeto de Vida são vislumbrados objetivos e fins e definidos quais os meios para atingí-los (Velho, 1994).

O delineamento do projeto de vida faz com que o adolescente possa pensar seu futuro, e a intervenção da equipe de saúde na atenção a violência sofrida pode fornecer elementos pra subsidiar esse Projeto livre deste contexto violento.

Aplicação da Linha de Cuidado: Utilizando as informações desta publicação, os profissionais podem fornecer elementos para que os adolescentes pensem seu Projeto de Vida e possam buscar meios de atingir seus objetivos.

\section{FLUXOGRAMA DE ATENÇÃO A VIOLÊNCIA NAS RELAÇÕES DE INTIMIDADE NO MUNICÍPIO DE GUARULHOS}

Após o embasamento téorico, filosófico e conceitual e a definição das práticas existentes no municipío de Guarulhos para prevenção e enfrentamento da violência nas relações de intimidade entre os adolescentes é proposto o fluxo que se segue para melhor entendimento do papel da atenção básica como ordenadora deste cuidado. 
Figura 3 - Fluxograma da Linha de Cuidado para prevenção e enfrentamento da violência nas relações de intimidade entre os adolescentes na atenção primária à saúde.

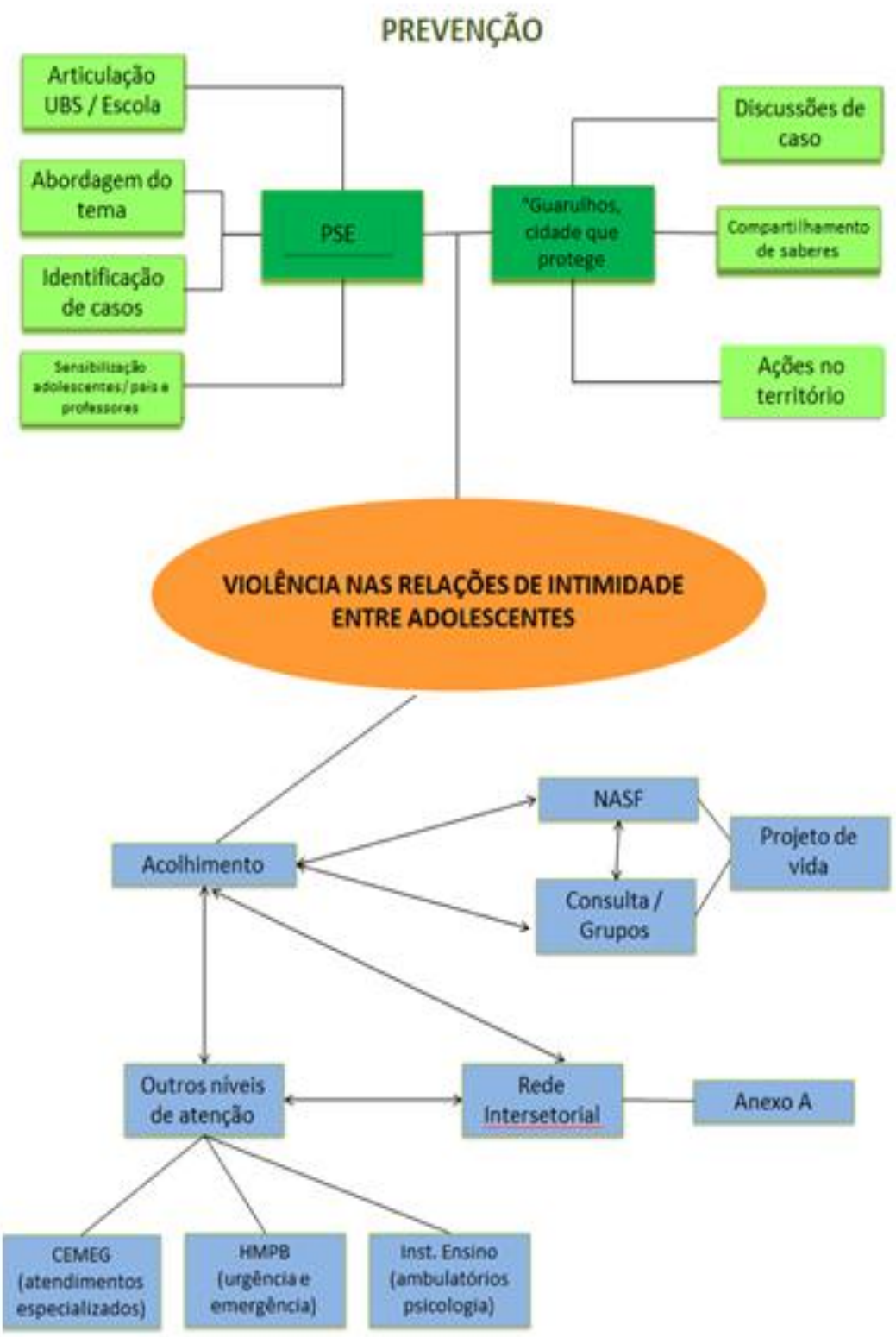




\section{CONSIDERAÇÕES FINAIS}

A Linha de Cuidado aqui apresentada teve por objetivo legitimar as práticas realizadas pelos profissionais da atenção básica no município de Guarulhos no manejo da violência nas relações de intimidade entre os adolescentes, introduzindo conceitos que possibilitem sua melhoria por meio da sistematização das ações.

Muitas dificuldades ainda podem ser encontradas, e possivelmente muitas situações não caberão a essa Linha de Cuidado, mas o profissional que conseguir se apoderar destes saberes poderá agir de maneira mais adequada e com maior eficiência e eficácia na atenção à saúde dos adolescentes do município.

O cuidado a essa população não deve ser realizado apenas pela Saúde e por isto estão citados em anexo os recursos existentes e as legislações vigentes no município de Guarulhos, para apoio intersetorial a fim de facilitar o trabalho dos profissionais de saúde no manejo a violência nas relações de intimidade entre os adolescentes. 


\section{REFERÊNCIAS}

Barra, SAR. Gestão da Estratégia Saúde da Família: o desafio de consolidar a intersetorialidade [dissertação]. Juiz de Fora: Universidade Federal de Juiz de Fora; 2013.

Bezerra KP, Monteiro Al. Violência intrafamiliar contra a criança: Intervenção de enfermeiros da estratégia saúde da família. Rev Rene. 2012;13(2):354-64.

Brasil. Decreto n. 6.286, de 5 de dezembro de 2007. Institui o Programa Saúde na Escola - PSE. Diário Oficial da União, Brasilia, 06 dez. 2007.

Brasil. Lei n. 8.069, de 13 de Julho de 1990. Dispõe sobre o Estatuto da Criança e do Adolescente. Diário Oficial da União, Brasília, 16 jul. 1990.

Brasil. Ministério Do Planejamento, Orçamento e Gestão, Instituto Brasileiro de Geografia e Estatística - IBGE, Diretoria de pesquisas Coordenação de população e Indicadores Sociais. Pesquisa Nacional de Saúde do Escolar. Rio de Janeiro; 2013.

Brasil. Ministério da Saúde. Secretaria de Atenção à Saúde. Departamento da Atenção Básica. Passo a passo PSE - Tecendo caminhos da intersetorialidade. Brasília; 2011.

Brasil. Ministério da Saúde. Secretaria de Atenção à Saúde. Departamento da Atenção Básica. Caderno do gestor do PSE. Brasília; 2015.

Brasil. Ministério da Saúde. Secretaria de Atenção à Saúde. Departamento de Ações Programáticas Estratégicas. Linha de cuidado para a atenção integral à saúde de crianças, adolescentes e suas famílias em situação de violências: orientação para gestores e profissionais. Brasília; 2010.

Campos GWS. Equipes de referência e apoio especializado matricial: um ensaio sobre a reorganização do trabalho em saúde. Cic Saúde Coletiva. 1999;4(2):393-403.

Catão, MF. Projeto de vida em construção na exclusão/inserção social. João Pessoa: Universitária; 2001.

Ciuffo RS, Ribeiro VIMB. Sistema Único de Saúde e a formação dos médicos: um diálogo possível?. Interface. 2008;12(24):125-140.

Dubow C, Olivo VMF, Ceron MI, Vedootto DO, Dal Moro JS, Oliveira $\mathrm{CP}$, Barbieri A. Linha de cuidado como dispositivo para a integralidade da atenção a usuários acometidos por agravos neoplásicos de cabeça e pescoço. Saúde Debate. 2014;38(100): 94103.

Franco TB, Junior HMM. Integralidade na assistência à Saúde: A organização das linhas do cuidado. In: Mehry et al. O Trabalho em 
Saúde: olhando e experienciando o SUS no cotidiano. São Paulo: Hucitec; 2004.

Gessner R, Fonseca RMGS, Oliveira RNG. Violência contra adolescentes: uma análise a luz das categorias gênero e geração. Rev Esc Enferm USP. 2014;48(N. Esp):104-10.

Gryschek ALFPL, Nichiata LYI, Fracolli LA, Oliveira MAF, Pinho PH. Tecendo a rede de atenção à saúde da mulher em direção à construção da linha de cuidado da gestante e puérpera, no Colegiado de Gestão Regional do Alto Capivari. Saúde Soc. 2014;23(2):689-700.

Guarulhos (Município). Secretaria da Saúde. Política Municipal de Promoção a Saúde. 2014.

Junges JR, Barbiani R. Repensando a Humanização do Sistema Único de Saúde à luz das Redes de Atenção à Saúde. O Mundo da Saúde. 2012;36(3):397-406.

Justo JS. O "ficar" na adolescência e paradigmas de relacionamento amoroso da contemporaneidade. Revista do Departamento de Psicologia - UFF. 2005;17(1):61-77.

Krug EG, Mercy JA, Dahlberg LL, Zwi AB. The world report on violence and health. The lancet. 2002;360 (9339):1083-8

Lima MADS, Ramos DD, Rosa RB, Nauderer TM, Davis R. Acesso e acolhimento em unidades de saúde na visão dos usuários. Acta Paul Enferm. 2007;20(1):12-17.

Magalhães Júnior HM, Oliveira RC. Concretizando a integralidade nos serviços de saúde. A aposta do SUS em Belo Horizonte. In: Pinheiro R, Ferla AA, Mattos RA, organizadores. Gestão em Redes: tecendo os fios da integralidade em saúde. Rio de Janeiro: EDUCS; 2006. p. 51-63.

Matos MS, Féres-Carneiro T, Jablonski B. Adolescência e relações amorosas: Um estudo sobre jovens das camadas populares. Interação. 2005;22:133-141.

Medeiros SM. Promoção da cultura de paz e prevenção das violências. In: Apresentado no 2 ํㅡㄴ Seminário do Programa Saúde na Escola; 2010; Guarulhos; 2010.

Mendonça CS. Gestão da Atenção Básica. Revista Brasileira de Saúde da Família. 2007.

Merhy EE. A perda da dimensão cuidadora na produção de saúde: uma discussão do modelo assistencial e da intervenção no seu modo de trabalhar a assistência. In: Campos CR, organizador. 
Sistema Único de Saúde em Belo Horizonte: reescrevendo o público. São Paulo: Editora Xamã; 1998. p. 103-120.

Minayo MCS, Assis SG, Njaine K, organizadoras. Amor e violência: um paradoxo das relações de namoro e do "ficar" entre jovens brasileiros. Rio de Janeiro: Fiocruz; 2011.

Oliveira MAC, Egry EY. A adolescência como um constructo social. Rev Bras Cresc Desenv Hum. 1997;7(2):20-7.

Oliveira DC, Gomes AMT, Marques SC, Thiengo MA. "Pegar", "ficar" e "namorar": representações sociais de relacionamentos entre adolescentes. Rev Bras Enferm. 2007;60(5):497-502.

Oliveira AR, Lyra J. Direitos sexuais e reprodutivos de adolescentes e as políticas públicas de saúde: desafios à atenção básica. Fazendo Gênero 8 - corpo, violência e Poder. 2008.

Oliveira SG, Ressel LB. Grupos de adolescentes na prática de enfermagem: um relato de experiência. Cienc Cuid Saude. 2010;9(1):144-48.

São Paulo (estado). Secretaria da Saúde. Atenção à gestante e puérpera no SUS: manual técnico do pré-natal e puerpério. São Paulo, 2010.

Soares CB, Avila LK, Salvetti MG. Necessidades (de saúde) de adolescentes do D.A. Raposo Tavares, SP, referidas à família, escola e bairro. Rev Bras Cresc Des Hum. 2000;10(2):19-34.

Tavares IL, Lima KS, Lima FDA, Costa MMF, Cunha FNV, Costa NPP. Ações educativas desenvolvidas por enfermeiros brasileiros com adolescentes vulneráveis às DST/AIDS. Cienc enferm. 2012;18(1):43-55.

Teixeira E, Aguiar SRV, Leal SYP, Lopes MG, Raymond TG, Cunha LKF, Machado TDP. Rev Enferm UFSM. 2014;4(1):197-205.

Velho G. Projeto e metamorfose: antropologia das sociedades complexas. Rio de Janeiro: Jorge Zahar; 1994.

Waiselfisz JJ. Mapa da Violência 2012. Os novos padrões da violência homicida no Brasil. São Paulo: Instituto Sangari; 2012.

WHO, World Health Organization. Young People's Health - a Challenge for Society. Report of a WHO Study Groupon Young People and Health for All. Technical Report Series 731. Geneva; 1986. 


\section{ANEXO A \\ SERVIÇOS DE APOIO INTERSETORIAL}

CONSELHOS TUTELARES

Região Centro (I)

Tel: (11) 2441-2437 / 2441-2438

Email: ctcentroguarulhos@hotmail.com

Região Cumbica (II)

Tel: (11) 2412-9062 / 2446-3760

Email: conselhocumbica@yahoo.com.br

Região São João / Bonsucesso (III)

Tel: (11) 2431-9081 / 2431-8485

Email: ctcsaojoaoguarulhos@ig.com.br

Região Pimentas (IV)

Tel: (11) 2498-2879 / 2431-8485

Email: ctpimentas@yahoo.com.br

Região Taboão (V)

Tel: (11) 2408-2824 / 2443-4057

Email:cttaboao@hotmail.com

CONSELHO MUNICIPAL DOS DIREITOS DA CRIANÇA E DO ADOLESCENTE - CMDCA

Tel: (11) 2408-5123 / 2461-4937

Email: cdmcaguarulhos@ig.com.br

Reuniões: $2^{a}$ terça feira de cada mês 
SECRETARIA DE DESENVOLVIMENTO E ASSISTÊNCIA SOCIAL CRAS - CENTRO DE REFERÊNCIA DA ASSISTÊNCIA SOCIAL ACÁCIO - (11) 2406-2113

CENTRO - (11) 2087-4275

ITAPEGICA - (11) 2421-0656

PONTE ALTA - (11) 2438-1507

CENTENÁRIO - (11) 2425-4369

CUMBICA - (11) 2411-1317

SANTOS DUMONT - (11) 2467-3315

SÃO JOÃO - (11) 2467-2535

PRESIDENTE DUTRA - (11) 2433-2882

PIMENTAS - (11) 2484-0809 ramais 204/205

NOVA CIDADE - (11) 2484-2813

CREAS - CENTRO DE REFERÊNCIA ESPECIALIZADO DA ASSISTÊNCIA SOCIAL

TEL: (11) 2467-5707 / 2467-5772

\section{SECRETARIA DA SAÚDE}

REFERÊNCIAS PARA ATENDIMENTO CASOS DE VIOLÊNCIA SEXUAL

Hospital Municipal da Criança e do Adolescente (HMCA)

Tel: (11) 2475-9688

Hospital Municipal Pimentas Bonsucesso

Tel: (11) 2489-6610

ACOMPANHEMENTO AMBULATORIAL - UNIDADE BÁSICA DE SAÚDE 
COORDENADORIA DA MULHER

Casa das Rosas, Margaridas e Beth's (Centro de Atendimento a mulher vítima de violência doméstica)

Tel: (11) 2475-9624

Casa da Mulher - Clara Maria I - Centro

Tel: (11) 2468 - 3569 / $2472-6926$

Casa da Mulher - Clara Maria II - Angélica

Tel: (11) 2480 - 1060

Casa da Mulher - Clara Maria III - Haroldo Veloso

Tel: (11) 2467 - 6445

Casa da Mulher - Clara Maria IV - Tranquilidade

Tel: (11) $2086-2374$

Casa da Mulher - Clara Maria V - Recreio São Jorge

Tel: (11) $2446-1576$

Casa da Mulher - Clara Maria VI - Ponte Alta

Tel: (11) 2087 - 2788 
ANEXO B

\section{LEGISLAÇÃO VIGENTE EM GUARULHOS SOBRE ADOLESCENTE}

\begin{tabular}{|c|c|}
\hline Nome & \begin{tabular}{c} 
Finalidade \\
\hline Decreto $\mathrm{n}^{0} 22855$ de $07 / 10 / 04$
\end{tabular} \\
\hline Decreto $\mathrm{n}^{\circ} 23475$ de $20 / 10 / 05$ & $\begin{array}{c}\text { Criar o Comitê Municipal de Enfrentamento á } \\
\text { Violência Doméstica e Sexual contra Crianças e } \\
\text { Adolescentes }\end{array}$ \\
\hline Decreto $\mathrm{n}^{\circ} 29756$ de $01 / 03 / 12$ & $\begin{array}{c}\text { Criar CEDAP - Centro de Diagnóstico, } \\
\text { Sexual de Crianças e Adolescentes de Guarulhos }\end{array}$ \\
\hline & $\begin{array}{c}\text { Instituir a Comissão Intersetorial para Elaboração, } \\
\text { Implementação e Acompanhamento do Plano } \\
\text { Municipal de Atendimento a Crianças e } \\
\text { Adolescentes }\end{array}$ \\
\hline
\end{tabular}

\begin{tabular}{|c|c|}
\hline Nome & Finalidade \\
\hline Lei $n^{\circ} 6160$ de 21/07/06 & $\begin{array}{c}\text { Programa de Incentivo às Atividades } \\
\text { Artísticas e Integração Social para crianças e } \\
\text { adolescentes }\end{array}$ \\
\hline Lei $n^{\circ} 6583$ de 19/11/09 & $\begin{array}{c}\text { Dispõe sobre criação do Programa Família } \\
\text { Acolhedora para crianças e adolescentes em } \\
\text { situação de risco social e dá outras } \\
\text { providências. }\end{array}$ \\
\hline Lei nº 6584 de 19/11/09 & $\begin{array}{c}\text { Cria o Orçamento Criança e Adolescente no } \\
\text { Município de Guarulhos, como instrumento de } \\
\text { controle social e fiscalização do orçamento público } \\
\text { na área da criança e do adolescente }\end{array}$ \\
\hline Lei $n^{\circ} 6587$ de 19/11/09 & $\begin{array}{c}\text { Dispõe sobre a criação do Disque Criança e } \\
\text { Adolescente, destinado a atender denúncias de } \\
\text { maus tratos, abandono ou } \\
\text { outra forma de violência contra adolescentes }\end{array}$ \\
\hline
\end{tabular}




\begin{tabular}{|c|c|}
\hline Lei $n^{\circ} 6635$ de 11/01/10 & $\begin{array}{c}\text { Cria o Cadastro Municipal de Registro de Casos de } \\
\text { Violência Contra Crianças e Adolescentes }\end{array}$ \\
\hline Lei $n^{\circ} 6665$ de 19/04/10 & $\begin{array}{l}\text { Institui Programa de Casas de Apoio, destinadas } \\
\text { ao atendimento de adolescentes grávidas, nas } \\
\text { comunidades carentes }\end{array}$ \\
\hline Lei $n^{\circ} 6747$ de 03/11/10 & $\begin{array}{l}\text { Dispõe sobre a oficialização da Rede Guarulhense } \\
\text { de não violência à mulher }\end{array}$ \\
\hline Lei $n^{\circ} 6766$ de 22/11/10 & $\begin{array}{c}\text { Dispõe sobre a obrigatoriedade dos } \\
\text { estabelecimentos citados a fixarem em lugar visível } \\
\text { cartaz alusivo aos crimes cometidos contra a } \\
\text { criança e ao adolescente, com número telefônico } \\
\text { da Secretaria Especial de Direitos Humanos } \\
\text { (SEDH) do Governo Federal }\end{array}$ \\
\hline Lei $n^{\circ} 6953$ de 21/11/11 & $\begin{array}{c}\text { Criação do Observatório de Proteção Integral à } \\
\text { Infância e Adolescência }\end{array}$ \\
\hline Lei $n^{\circ} 7425$ de $11 / 12 / 15$ & $\begin{array}{l}\text { Implanta o Conselho Municipal da Juventude, } \\
\text { institui o Fundo Municipal da Juventude }\end{array}$ \\
\hline Lei $n^{0} 7463$ de 14/03/16 & $\begin{array}{l}\text { Obriga o Poder Executivo Municipal a afixar } \\
\text { cartazes contendo o artigo } 4^{\circ} \text { do Estatuto da } \\
\text { Criança e do Adolescente em Hospitais, UBS's, } \\
\text { Creches, e Escolas Municipais }\end{array}$ \\
\hline
\end{tabular}


ANEXO C

\section{FLUXOGRAMA DE ATENÇÃO A VÍTIMA DE VIOLÊNCIA SEXUAL DO MUNICÍPIO DE GUARULHOS}

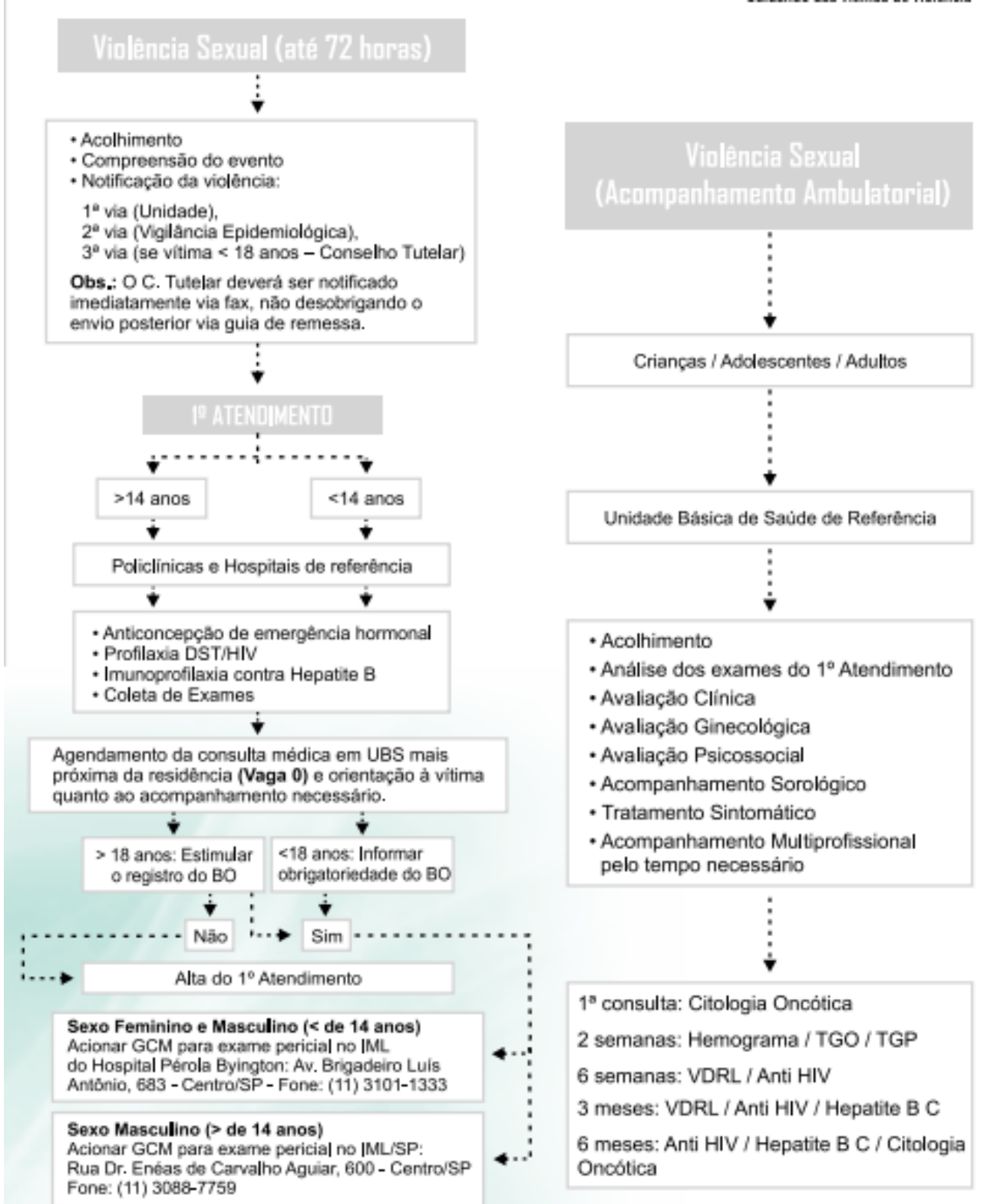

Fonte: Guarulhos. Projeto llumiar. Atenção às vítimas de violência sexual em Guarulhos. 2014. 


\section{DISCUSSÃO}

$\mathrm{Na}$ busca realizada para este estudo, percebeu-se que as políticas que versam sobre o adolescente, vigentes no município de Guarulhos, refletem uma visão biologicista da adolescência, trazendo a definição somente de acordo com a faixa etária.

Percebe-se ainda que a legislação vigente ainda está desconectada da realidade e assim como aconteceu com a Política Nacional de Atenção Integral à Saúde de Adolescentes e Jovens (PNASIAJ), criada pelo Ministério da Saúde, a aplicabilidade destas políticas estão prejudicadas, como refere Lopez e Moreira (2013):

"como categoria, a adolescência e a juventude
ainda se encontram confrontados pelas disputas
por um protagonismo social mais ampliado e
responsável, para além de um
"pseudoprotagonismo juvenil" ou "protagonismo
tutelado" submetido a um olhar adultocêntrico, que
se coloca como porta-voz das vozes adolescentes
e jovens, paradoxalmente, silenciando-os." (Lopez
e Moreira, 2013, p. 1185)

As políticas públicas existentes para atender a adolescência e ao adolescente vítima de violência são desenvolvidas apenas pelo setor saúde, inexistindo, ou existindo de forma muito incipiente a ação intersetorial, de extrema importância neste contexto.

Para Paixão e Deslandes (2010), é necessária a universalização das ações entre os diferentes setores da sociedade, que possam suprir as necessidades desta população. Não é possível deixar a saúde como principal atuante, porque os adolescentes necessitam de ações de outros setores para enfrentar situações de violência. Como exemplo, pode ser citada a Assistência Social, que pode desenvolver ações de geração de renda para romper com a dependência da vítima no caso de violência de gênero. 
Sposito e Carrano (2003), ao analisarem as politicas públicas nacionais referentes juventude trazem como preocupação o fato desta população ter sido historicamente contemplada dentro de outras políticas que abrangessem todas as faixas etárias.

Além disso, a adolescência trás um estigma de uma fase de irresponsabilidade para a sociedade, logo, o adolescente não é chamado a interferir nas políticas que dizem respeito a ele. Pelo fato dos adolescentes não fazerem parte das formulações de políticas públicas que os representem, ocorre que:

\begin{abstract}
"a conformação das ações e programas públicos não sofre apenas os efeitos de concepções, mas pode, ao contrário, provocar modulações nas imagens dominantes que a sociedade constrói sobre seus sujeitos jovens. Assim, as políticas públicas de juventude não seriam apenas o retrato passivo de formas dominantes de conceber a condição juvenil, mas poderiam agir, ativamente, na produção de novas representações" (Sposito e Carrano, 2003, p.18)
\end{abstract}

Desta maneira, um determinante que interfere no cuidado à saúde do adolescente é a concepção de adolescência presente no discurso dos profissionais, como seres incapazes, irresponsáveis e conflituosos.

Para Oliveira e Lyra (2008), este pensamento torna-se uma dificuldade na atenção a saúde do adolescente porque os profissionais não consideram esta população composta por sujeitos de direitos, por serem imaturos e irresponsáveis.

\footnotetext{
"Embora sejam vistos como os depositários das possibilidades de mudança, de um melhor prognóstico para o mundo, adolescentes são percebidos pelos adultos em geral como sujeitos que não têm autonomia frente aos seus direitos e desejos nos campos da sexualidade e reprodução" (Oliveira e Lyra, 2008)
}

Esta concepção dificulta a horizontalidade das relações que é necessária no atendimento a essa população, buscando tornar o serviço de saúde atrativo às demandas que interessam ao 
adolescente e favorecem também sua adesão e vínculo ao sistema (Oliveira e Lyra, 2008).

No que diz respeito ao conceito de violência, na maioria dos relatos foi verificado que predomina a concepção da multicausalidade, ou seja, os sujeitos de pesquisa acreditam que a violência se deve a múltiplos e diferentes fatores que, somados, ocasionam as situações de violência.

Ao aderirem a esta concepção, os profissionais manifestam que há:

"[...] impossibilidade de conhecer o peso relativo de cada um dos fatores na determinação do fenômeno. Outra, ao fato dos modelos empíricos em epidemiologia trabalharem tais fatores isoladamente, sendo capazes, no máximo, de controlar os intervenientes, paradoxo que resulta na sua redução à unicausalidade. A sua aplicabilidade na formulação de políticas de saúde também esbarra na dificuldade de estabelecer prioridades para a atuação frente a inúmeras opções causais". (Oliveira e Egry, 2000, p.12)

Alguns participantes manifestaram que a violência é um fenômeno de construção histórica e social, aderente à visão da Teoria da Determinação Social do Processo Saúde Doença.

Em estudo de revisão de literatura feito por Oliveira et al.,

(2016), acerca da prevenção da violência por parceiro íntimo na adolescência demonstrou-se a magnitude desta problemática, porém são escassos os estudos que abordavam a prevenção sobre a ótica da Teoria da Determinação Social do Processo Saúde Doença, e assim como encontrado nesta revisão, poucos profissionais souberam reconhecer o contexto da violência determinado pelo contexto social aos que os adolescentes estão inseridos. 
Entender o adolescente como ser social, construído e transformado histórico, cultural e socialmente, permite aos profissionais compreender a dinâmica da adolescência. Implica compreender os adolescentes como seres transformadores da sociedade e de sua saúde, o que favorece o cuidado prestado. .

Estudo realizado por Trabold et al. (2016), realizado com 10 profissionais de saúde atuantes em estratégia saúde da família, que procurou conhecer as concepções sobre adolescentes em situação de violência concluiu que as ações voltadas para a prevenção da violência são escassas e pontuais. Isto evidencia a negação ou omissão dos serviços e trabalhadores, também porque eles acreditam que este ainda é um grande desafio para a atenção à saúde.

Mesmo reconhecendo o avanço das políticas, percebe-se que o problema está no entendimento dos profissionais e também na falta de recursos para o manejo da violência.

\footnotetext{
"A implementação da política de atenção à saúde do adolescente no Brasil esbarra na carência e na formação dos recursos humanos: não há suficientes equipes de saúde para a população; as equipes não estão capacitadas/sensibilizadas para o trabalho com adolescentes; mesmo as que passaram por períodos de formação, nem todos os profissionais se dispõem a trabalhar com esta população; muitos profissionais, embora capacitados, ainda percebem os adolescentes como pessoas em formação, que precisam de orientação e tutela, e não têm maturidade suficiente para exercer plenamente seus direitos." (Oliveira e Lyra, 2008, p.5)
}

Nas falas dos participantes foi percebido a importância do trabalho junto às escolas no Programa Saúde do Escolar (PSE). Percebe-se também que os profissionais reconhecem esta política pública existente no município e a utilizam em seu cotidiano. 
Trata-se de um espaço instituído na assistência e na gestão, portanto, pode ser trabalhada a prevenção e o enfrentamento da violência entre os adolescentes, bem como outros assuntos pertinentes à saúde dessa população.

Além do Programa Saúde na Escola, no município de Guarulhos, existe outro espaço para discussão da violência. Trata-se de um projeto que versa sobre a prevenção da violência denominado "Guarulhos, cidade que protege", integrante do componente III do PSE.

São feitos encontros interdisciplinares e intersetoriais, envolvendo profissionais e gestores da saúde, da educação, do Centro de Referência de Assistência Social (CRAS), do Centro de Referência Especializado de Assistência Social (CREAS), do poder judiciário e da população para discussão e manejo, em rede, dos casos de violência ocorridos.

Este projeto foi iniciado em 2010, mediante parceria entre as Secretarias da Saúde, da Educação, da Assistência Social e a Universidade Federal de São Paulo (UNIFESP). Inicialmente, foi realizado um curso denominado "Escola Protetora". Seu objetivo foi compartilhar, com educadores, educadoras e outros profissionais, informações sobre as diferentes formas de violência a que crianças e adolescentes estão submetidos, visando subsidiar ações práticas de enfrentamento à violência no contexto escolar e social, tendo o Estatuto da Criança e do Adolescente (ECA) como referência.

Os encontros, denominados "Guarulhos, cidade que protege", tiveram início após o término do curso, com os atores do Distrito Água Chata. Têm por objetivos:

- Mobilizar os atores locais: escolas, unidades básicas de saúde, centros de referência de assistência social, conselho tutelar, entre outros, para potencializar suas ações de prevenção e promoção no território; 
- Construir um projeto piloto para o enfrentamento das violências contra crianças e adolescentes, visando tornar-se referência para o município. (Medeiros, 2010)

Os encontros são realizados uma vez por mês e são discutidos casos ou são chamados convidados para realizar reflexões sobre temáticas referentes à prevenção das violências junto às crianças e aos adolescentes, inseridos no sistema de educação da cidade de Guarulhos.

Pode-se reconhecer que a união de um grupo multiprofissional e intersetorial para discussão em conjunto de casos para prevenção é um grande avanço para implementação das políticas instituídas no município. Ao lado disso, a falta dessa organização é um dos dificultadores da equipe de saúde da família para o manejo das situações de violência (Bezerra e Monteiro, 2012)

No entanto, mesmo sendo um avanço, pode-se observar que nesses encontros são tratadas sempre das mesmas temáticas e os mesmos casos índices, não se aprofundando nos estudos ou nas práticas efetivas de manejo das violências no município.

Outra estratégia utilizada para prevenção e enfrentamento das questões de violência entre os adolescentes é o apoio multiprofissional, caracterizado pela ação do NASF.

O Sistema Único de Saúde (SUS) tem como uma de suas diretrizes o acesso à assistência, onde a atenção primária à saúde, materializada no modelo da estratégia saúde da família, tem papel regulador de fluxo, podendo garantir a equidade no acesso aos meios de saúde (Merhy, 1998).

Além disso, o SUS tem o papel de ordenador de recursos humanos na área de saúde o que implica retirar o foco das ações assistencialistas e entender que o cuidado deve conjugar ações de prevenção e promoção da saúde, além da cura e da reabilitação. 
Todas estas ações exigem pluralidade de saberes e o trabalho em equipe interdisciplinar e multiprofissional, preferencialmente em rede (Ciuffo e Ribeiro, 2008).

Uma das ferramentas utilizadas para 0 trabalho multidisciplinar e integral é o apoio matricial. Tem por objetivo ampliar a resolubilidade dos serviços através do apoio técnico oferecido por diferentes profissionais numa relação horizontal entre as especialidades (Campos, 1999).

Em 2010, foram criados os Núcleos de Apoio à Saúde da Família (NASF) e à Atenção Básica (NAAB), tendo como uma de suas diretrizes o fortalecimento das ações de Promoção da Saúde. Esses núcleos, assim como as Redes de Atenção à Saúde fazem parte de um processo transversal no desenvolvimento da promoção à saúde.

Com o apoio do NASF, as equipes de atenção básica (EAB) realizam grupos com os adolescentes. Esta estratégia também pode ser considerada uma prática de enfrentamento da violência nas relações de intimidade entre os adolescentes, quando essa temática for abordada, pois favorece a interação entre os adolescentes e os profissionais.

É importante manter a concepção de que o adolescente é capaz de decidir sobre o que quer, que é sujeito de direitos e opiniões para garantir adesão a esse tipo de abordagem, aproveitando esta oportunidade para incentivar sua tomada de decisão em relação à saúde e sua cidadania no processo educativo (Teixeira et al., 2014).

As temáticas devem partir do adolescente, utilizando metodologia participativa, proporcionando reflexão e diálogo, favorecendo a formação de vínculo entre o participante e o profissional (Oliveira, Ressel, 2010). 
A realização dos grupos sobre violência na unidade, abordada a partir de sugestões dos adolescentes e com metodologias motivadoras contribuem para a mudança de comportamento e enfrentamento da violência, melhorando a qualidade de vida (Tavares et al., 2012).

Outra forma de manejo desta situação descrita pelos participantes é a utilização do acolhimento, caracterizado como o primeiro contato entre o profissional e a adolescente.

No acolhimento, o profissional procura se aproximar da demanda trazida pelo adolescente a fim de prestar o cuidado de maneira integral as diferentes situações apresentadas. De acordo com a Política Nacional de Humanização, publicada em 2010 pelo MS, o acolhimento deve ser entendido como um momento de escuta qualificada. É responsável pelo estabelecimento de vínculos entre o usuário e o profissional. Isto irá influenciar diretamente a eficiência e eficácia do atendimento prestado (Lima et al., 2007).

Para os participantes, o acolhimento é momento privilegiado para as orientações sobre os diversos temas que envolvem a situação de violência, para a oferta dos serviços disponíveis, para a notificação e denúncia do caso e realização dos diferentes encaminhamentos propostos (Brasil, 2010).

Os profissionais também reforçaram a importância do auxílio na construção do Projeto de Vida dos adolescentes. O projeto de vida pode ser definido como uma possibilidade de transformação do futuro através de representação social do contexto de inserção do adolescente, bem como da possibilidade de transformação desta realidade (Catão, 2001).

Durante a construção do Projeto de Vida são vislumbrados objetivos e fins e definidos quais os meios para atingi-los (Velho, 1994).

Em estudo realizado por Teixeira, 2005 com jovens de 
comunidades carentes do Rio de Janeiro, foi verificado que os jovens sabem o que querem para o futuro, mas não conseguem relacionar seus desejos com o presente, necessitando de auxílio para alcançar os meios a fim de atingir seus objetivos.

\footnotetext{
"O Projeto de Vida é também uma forma de dar-se a conhecer para si e para os outros por meio dos anseios, dos planos de vida e da ampliação de possibilidades que articulam realizações, como ter uma profissão, um trabalho, casar, ter filhos, ter acesso aos bens de consumo (casa, carro, apartamento etc.)." (Nascimento, 2006)
}

A partir da análise que o adolescente faz do mundo em que vive, de suas relações e seu contexto, eles podem construir seus Projetos de Vida (Nascimento, 2006). É indiscutível o poder de transformação social que o adolescente tem na sociedade atual, porém, muitas vezes ele próprio não consegue reconhecer essa potencialidade, em meio a vulnerabilidade em que está inserido (Moura, Almeida, 2012).

O Ministério da Saúde (2010), em suas Diretrizes para Atenção Integral ao Adolescente, destaca o Projeto de Vida como um tema estruturante para guiar as ações ofertadas aos adolescentes, entendendo como uma forma de fortalecer a identidade pessoal, a responsabilidade e a auto-estima visando a melhoria do futuro desta população.

O delineamento do Projeto de Vida faz com que o adolescente possa pensar seu futuro, e a intervenção da equipe de saúde na atenção a violência sofrida pode fornecer elementos pra subsidiar esse Projeto livre do contexto violento.

$\mathrm{Na}$ assistência prestada aos adolescentes, um dos grandes dificultadores apresentados foi a falta de apoio ou desconhecimento de serviços intersetoriais que possam atuar junto ao cuidado dessa população.

Essa informação é ratificada quando se observam a escassez 
de Políticas Públicas nesta área, e o direcionamento das existentes para a Assistência Social, sem inclusão da Saúde prejudicando a integração intersetorial.

Assim como afirma Blay (2003) é necessária a articulação entre os diferentes setores do governo e da sociedade para produzir Políticas Públicas para o enfrentamento da violência atendendo o sujeito envolvido de acordo com a situação vivenciada. 
CONSIDERACÕES FINAIS 


\section{CONSIDERAÇÕES FINAIS}

Considerando as políticas existentes no município de Guarulhos que versam sobre a saúde do adolescente ou o adolescente em situação de violência, percebe-se uma lacuna entre o que está proposto e as percepções dos profissionais que atuam com esta população.

Além da falta de publicidade desta legislação, nota-se ainda que as definições sobre adolescente e adolescência referem-se tão somente à faixa etária que integra esta população, desconectada do contexto social em que ela está inserida.

No que diz respeito aos profissionais, a maioria dos participantes tinha experiência no atendimento à população adolescente, porém não foram capacitados para isto. Mesmo assim são realizadas ações voltadas para a prevenção e o enfrentamento as situações de violência entre os adolescentes nas relações de intimidade quando identificadas.

É necessário investir na educação dos profissionais para a transformação sobre as concepções acerca de adolescência, de processo saúde - doença e consequentemente violência a fim de melhorar a eficiência e a eficácia das ações desenvolvidas para esta população.

Pensando nisso, a linha de cuidado proposta neste estudo tem como finalidade auxiliar a formação dos profissionais da atenção primária do município de Guarulhos para o atendimento dos adolescentes vítimas de violência de seu território, atendimento este entendido como imediato, e também as ações de prevenção.

Para isto foram consideradas as experiências e relatos das práticas já realizadas por estes profissionais, buscando complementar os conceitos que embasam as ações. 
Finalmente, é necessário divulgar e levar ao conhecimento de toda a rede os recursos existentes e as políticas públicas vigentes no município de Guarulhos, de apoio intersetorial para facilitar o trabalho nesta área.

A linha de cuidado elaborada, poderá ser adotada nos serviços de saúde para facilitar a implementação das práticas na atenção a esta população. Também servirá para capacitar e qualificar os recursos humanos envolvidos e necessários, bem como estudantes. 


\section{REFERÊNCIAS}

Bardin L. Análise de Conteúdo. Lisboa: Edições 70; 2009.

Bezerra KP, Monteiro Al. Violência intrafamiliar contra a criança: Intervenção de enfermeiros da estratégia saúde da família. Rev Rene. 2012;13(2):354-64.

Blay EA. Violência contra a mulher e políticas públicas. Estud. av. 2003;17(49):87-98.

Brancaglioni BCA, Fonseca RMGS. Violência por parceiro íntimo na adolescência: uma análise de Gênero e geração. Revista Bras Enferm. 2016;69(5).

Brasil. Decreto n. 6.286, de 5 de dezembro de 2007. Institui o Programa Saúde na Escola - PSE. Diário Oficial da União, Brasilia, 06 dez. 2007.

Brasil. Decreto n. 7.508, de 28 de junho de 2011. Regulamenta a Lei no 8.080 , de 19 de setembro de 1990, para dispor sobre a organização do Sistema Único de Saúde - SUS, o planejamento da saúde, a assistência à saúde e a articulação interfederativa, e dá outras providências. Diário Oficial da União, Brasilia, 29 jun. 2011.

Brasil. Lei n. 8.069, de 13 de Julho de 1990. Dispõe sobre o Estatuto da Criança e do Adolescente. Diário Oficial da União, Brasília, 16 jul. 1990.

Brasil. Ministério da Saúde. HumanizaSUS. Política Nacional de Humanização. Brasília; 2004.

Brasil. Ministério Do Planejamento, Orçamento e Gestão, Instituto Brasileiro de Geografia e Estatística - IBGE, Diretoria de pesquisas Coordenação de população e Indicadores Sociais. Pesquisa Nacional de Saúde do Escolar. Rio de Janeiro; 2013.

Brasil. Ministério da Saúde. Secretaria de Atenção à Saúde. Departamento da Atenção Básica. Passo a passo PSE - Tecendo caminhos da intersetorialidade. Brasília; 2011.

Brasil. Ministério da Saúde. Secretaria de Atenção à Saúde. Departamento da Atenção Básica. Caderno do gestor do PSE. Brasília; 2015.

Brasil. Ministério da Saúde. Secretaria de Atenção à Saúde. Departamento de Ações Programáticas Estratégicas. Linha de cuidado para a atenção integral à saúde de crianças, adolescentes e suas famílias em situação de violências: orientação para gestores e profissionais. Brasília; 2010.

Brasil. Secretaria Geral da Presidência da República. Secretaria Nacional de Juventude. Secretaria de Políticas de Promoção da 
Igualdade Racial. Mapa da violência: Mortes matadas por arma de fogo. Brasília; 2015.

Brasil. Ministério da Saúde . Secretaria de Atenção à Saúde. Núcleo Técnico da Política Nacional de Humanização. Acolhimento nas práticas de produção de saúde. Brasília; 2010.

Campos GWS. Equipes de referência e apoio especializado matricial: um ensaio sobre a reorganização do trabalho em saúde. Cic Saúde Coletiva. 1999;4(2):393-403.

Catão, MF. Projeto de vida em construção na exclusão/inserção social. João Pessoa: Universitária; 2001.

Ciuffo RS, Ribeiro VIMB. Sistema Único de Saúde e a formação dos médicos: um diálogo possível?. Interface. 2008;12(24):125-140.

Dubow C, Olivo VMF, Ceron MI, Vedootto DO, Dal Moro JS, Oliveira CP, Barbieri A. Linha de cuidado como dispositivo para a integralidade da atenção a usuários acometidos por agravos neoplásicos de cabeça e pescoço. Saúde Debate. 2014;38(100): 94103.

Fernández-Fuertes AA, Fuertes $U$. Physical and psychological aggression in dating relationships of Spanish adolescents: motives and consequences. Child Abuse Negl. 2010;34(3):183-91.

Fonseca F. Dimensões críticas das políticas públicas. Cad. EBAPE. 2013;11(3):402-18.

Fonseca RMGS, Egry EY, Bertolozzi MR. O materialismo histórico e dialético como teoria da cognição e método para a compreensão do processo saúde doença. In: Egry EY, Cubas MR, Organizadoras. O trabalho da Enfermagem em Saúde Coletiva no cenário CIPESC. Curitiba: Associação Brasileira de Enfermagem. 2006. p. 19-61.

Gessner R. Violência contra o adolescente: uma análise à luz das categorias gênero e geração [dissertação]. São Paulo: Escola de Enfermagem, Universidade de São Paulo; 2013.

Gessner R, Fonseca RMGS, Oliveira RNG. Violência contra adolescentes: uma análise a luz das categorias gênero e geração. Rev Esc Enferm USP. 2014;48(N. Esp):104-10.

Gil AC. Como elaborar projetos de pesquisa. 4르 ed. São Paulo: Atlas; 2007.

Gryschek ALFPL, Nichiata LYI, Fracolli LA, Oliveira MAF, Pinho PH. Tecendo a rede de atenção à saúde da mulher em direção à construção da linha de cuidado da gestante e puérpera, no Colegiado de Gestão Regional do Alto Capivari. Saúde Soc. 2014;23(2):689-700.

Guarulhos (Município). Lei n. 6.946, de 17 de Novembro de 2011. 
Dispõe sobre a criação do Programa saúde na adolescência e dá outras providências. Diário Oficial do Município de Guarulhos. 2011.

Guarulhos (Município). Secretaria de Habitação. Plano local de habitação de interesse social de Guarulhos. Diagnóstico do Setor Habitacional. Etapa II. 2011.

Guarulhos (Município). Secretaria da Saúde. Política Municipal de Promoção a Saúde. 2014.

Guarulhos (Município). Secretaria da Saúde. Política Municipal de Práticas Integrativas e Complementares em Saúde. 2014.

Guarulhos (Município). Secretaria da Saúde. Curso Introdutório Atenção Básica. 2014.

Junges JR, Barbiani R. Repensando a Humanização do Sistema Único de Saúde à luz das Redes de Atenção à Saúde. O Mundo da Saúde. 2012;36(3):397-406.

Justo JS. O "ficar" na adolescência e paradigmas de relacionamento amoroso da contemporaneidade. Revista do Departamento de Psicologia - UFF. 2005;17(1):61-77.

Lima MADS, Ramos DD, Rosa RB, Nauderer TM, Davis R. Acesso e acolhimento em unidades de saúde na visão dos usuários. Acta Paul Enferm. 2007;20(1):12-17.

Lopez SB, Moreira MCN. Quando uma proposição não se converte em política: O caso da Política Nacional de Atenção Integral à Saúde de Adolescentes e Jovens - PNAISAJ. Ciênc Saúde Coletiva. 2013;18(4):1179-1186.

Magalhães Júnior HM, Oliveira RC. Concretizando a integralidade nos serviços de saúde. A aposta do SUS em Belo Horizonte. In: Pinheiro R, Ferla AA, Mattos RA, organizadores. Gestão em Redes: tecendo os fios da integralidade em saúde. Rio de Janeiro: EDUCS; 2006. p. 51-63.

Marinho CCC, Conceição CS, Santos MLMF, Carvalho SM, Menezes TMO, Guimarães EP. O olhar de uma equipe multiprofissional sobre as linhas de cuidado: (vi)vendo o tecer dos fios. Rev Baiana de Saúde Pública. 2011;35(3):619-33.

Matos MS, Féres-Carneiro T, Jablonski B. Adolescência e relações amorosas: Um estudo sobre jovens das camadas populares. Interação. 2005;22:133-141.

Medeiros SM. Promoção da cultura de paz e prevenção das violências. In: Apresentado no $2^{\circ}$ Seminário do Programa Saúde na Escola; 2010; Guarulhos; 2010.

Merhy EE. A perda da dimensão cuidadora na produção de saúde: uma discussão do modelo assistencial e da intervenção no seu modo de trabalhar a assistência. In: Campos CR, organizador. 
Sistema Único de Saúde em Belo Horizonte: reescrevendo o público. São Paulo: Editora Xamã; 1998. p. 103-120.

Minayo, MCS. Pesquisa social. Teoria, método e criatividade. $18^{a}$ ed. Petrópolis: Vozes; 2001.

Minayo MCS, Assis SG, Njaine K, organizadoras. Amor e violência: um paradoxo das relações de namoro e do "ficar" entre jovens brasileiros. Rio de Janeiro: Fiocruz; 2011.

Moura RR, Almeida DC. Adolescentes e construção do projeto de vida: apontamentos a partir da realidade de Ponta Grossa-PR. Âmbito Jurídico. 2012;106.

Muñoz-Rivas MJ, Graña JL, O'Leary KD, Gonzáles MP. Aggression in adolescente dating relationships: prevalence, justification and health consequences. J Adolesc Health. 2007;40:298-304.

Murphy KA, Smith DI. Adolescent girls' responses to warning signs of abuse in romantic relationships: implications for youth-targeted relationship violence prevention. $J$ Interpers Violence. 2010;25(4):626-47.

Nascimento IP. Projeto de vida de adolescentes do ensino médio: um estudo psicossocial sobre suas representações. Imaginario. 2006;12(12):55-80.

Neto FRGX, Dias MAS, Rocha J, Cunha ICKO. Gravidez na adolescência: motivos e percepções de adolescentes. Rev Bras Enferm. 2007;60(3):279-84.

O'Leary KD, Smith Slep AM, Avery SF, Cascardi M. Gender differences in dating aggression among multiethnic high school students. J Adolesc Health. 2008;42(5):473-9.

Oliveira MAC, Egry EY. A adolescência como um constructo social. Rev Bras Cresc Desenv Hum. 1997;7(2):20-7.

Oliveira MAC, Egry EY. A historicidade das teorias interpretativas do processo saúde-doença. Rev Esc Enf USP. 2000;34(1):9-15.

Oliveira DC, Gomes AMT, Marques SC, Thiengo MA. "Pegar", "ficar" e "namorar": representações sociais de relacionamentos entre adolescentes. Rev Bras Enferm. 2007;60(5):497-502.

Oliveira AR, Lyra J. Direitos sexuais e reprodutivos de adolescentes e as políticas públicas de saúde: desafios à atenção básica. Fazendo Gênero 8 - corpo, violência e Poder. 2008.

Oliveira RNG, Gessner R, Brancaglioni BCA, Fonseca RMGS, Egry EY. Preventing violence by intimate partners in adolescence: an integrative review. Rev Esc Enferm USP. 2016;50(1):134-43.

Oliveira SG, Ressel LB. Grupos de adolescentes na prática de enfermagem: um relato de experiência. Cienc Cuid Saude. 2010;9(1):144-48. 
Paixão ACW, Deslandes SF. Análise das políticas públicas de enfrentamento da violência sexual infantojuvenil. Saúde e Sociedade. 2010;19(1):114-126.

São Paulo (estado). Secretaria da Saúde. Atenção à gestante e puérpera no SUS: manual técnico do pré-natal e puerpério. São Paulo, 2010.

Silva SP. Considerações sobre o relacionamento amoroso entre adolescentes. Cad Cedes. 2002;22(57):23-43.

Silva CL, Bassi NSS. Políticas públicas e desenvolvimento local. In: Silva CL, organizador. Políticas Públicas: desenvolvimento local; Petrópolis: Vozes; 2012. p.15-38.

Soares CB, Avila LK, Salvetti MG. Necessidades (de saúde) de adolescentes do D.A. Raposo Tavares, SP, referidas à família, escola e bairro. Rev Bras Cresc Des Hum. 2000;10(2):19-34.

Souza C. Políticas públicas: uma revisão da literatura. Sociologias. 2006;8(16):20-45.

Souza FN, Costa AP, Moreira A. Análise de Dados Qualitativos Suportada pelo Software webQDA". In: Atas da VII Conferência Internacional de TIC na Educação: Perspectivas de Inovação; 2011 mai 12-13; Braga. 2011. p. 49-56.

Sposito MP, Carrano PCR. Juventude e políticas públicas no Brasil. Rev. Bras. Educ. 2003;24:16-39.

Tavares IL, Lima KS, Lima FDA, Costa MMF, Cunha FNV, Costa NPP. Ações educativas desenvolvidas por enfermeiros brasileiros com adolescentes vulneráveis às DST/AIDS. Cienc enferm. 2012;18(1):43-55.

Teixeira E, Aguiar SRV, Leal SYP, Lopes MG, Raymond TG, Cunha LKF, Machado TDP. Rev Enferm UFSM. 2014;4(1):197-205.

Teixeira EJ. Juventude pobre, participação e redes de sociabilidade na construção do projeto de vida [dissertação]. Rio de Janeiro: Universidade Federal do Rio de Janeiro; 2005.

Trabbold VLM, Caleiro RCL, Cunha CF, Guerra AMC. Concepções sobre adolescentes em situação de violência sexual. Psicologia \& Sociedade. 2016;28(1):74-83.

Trivinos ANS. Introdução à pesquisa em Ciências Sociais: a pesquisa qualitativa em educação. São Paulo: Atlas; 1987.

Velho G. Projeto e metamorfose: antropologia das sociedades complexas. Rio de Janeiro: Jorge Zahar; 1994.

Waiselfisz JJ. Mapa da Violência 2012. Os novos padrões da violência homicida no Brasil. São Paulo: Instituto Sangari; 2012. 
WHO, World Health Organization. Young People's Health - a Challenge for Society. Report of a WHO Study Groupon Young People and Health for All. Technical Report Series 731. Geneva; 1986. 
APÊNDICES 


\section{APÊNDICE 1}

\section{QUESTIONÁRIO CARACTERIZAÇÃO DOS PARTICIPANTES}

\section{Dados de identificação}

Unidade que trabalha:

Idade (anos completos):

Sexo: Feminino ( ) Masculino ( )

Cor / Raça: Negro ( ) Branco ( ) Amarelo ( )

Estado civil: Solteiro（） Casado（） União estável（）

$$
\text { Divorciado / Separado ( ) Viúvo ( ) }
$$

Dados sobre formação / atuação profissional

- Formação:

- Tempo de formação (em anos completos)

- Formação complementar:

- Tempo de serviço na prefeitura:

- Tempo de serviço na unidade atual:

- Já participou do PSE:

Sim ( ) Não ( ) Caso sim, de que maneira?

- Possui experiência no atendimento de adolescentes:

Sim ( ) Não ( ) Caso sim, que tipo?

- Possui experiência no atendimento as vítimas de violência:

Sim ( ) Não ( ) Caso sim, que tipo? 


\section{APÊNDICE 2}

\section{QUESTIONÁRIO}

\begin{tabular}{|l|l|l|}
\hline $\begin{array}{l}\text { Projeto de Pesquisa: “Linha de cuidado para } \\
\text { prevenção e enfrentamento da violência nas relações } \\
\text { de intimidade entre adolescentes" }\end{array}$ & Data Código \\
\hline Pesquisadora: Kátia Darbello da Silva & & \\
\hline
\end{tabular}

\section{SITUAÇÃO}

Anabela tem 15 anos e namora Ricardo que tem 17 anos. Estudam na mesma escola, em classes diferentes. Conheceram-se porque ele era amigo de um amigo dela. Numa festa "ficaram" e daí algum tempo resolveram namorar.

Antes de Ricardo, Anabela nunca tinha namorado. Às vezes "ficava" com algum rapaz, mas nunca havia namorado de verdade. Ricardo, ao contrário, sempre teve muitas namoradas. Mesmo durante o namoro com a Anabela, "ficou" várias vezes com outras meninas da escola. Anabela desconfiou mas nunca disse nada. Quando ela tentava tocar no assunto, ele ficava nervoso e falava em terminar o namoro. Outra coisa que ele faz e que ela se incomoda mas não fala nada é que Ricardo anda sempre com um grupo de rapazes que gosta de gozar dos mais novos, dos não brancos, dos homossexuais e outros "diferentes". Ela acha que ele é nervoso porque tem um irmão que é paraplégico e o pai usa droga, por isso, toma muito cuidado para não provocar sua raiva.

Ele também é muito ciumento. Gosta de ter Anabela sempre por perto. Ela quase não pode falar nem sair com as amigas. Ele insiste em ver o seu facebook e whatsapp para saber quem são seus amigos. Às vezes manda ela bloquear alguns contatos ou aceitar outros. Diz que é para o bem dela e do relacionamento deles.

Um dia, estavam os dois sozinhos na casa da Anabela e ele quis fazer sexo anal, diferente do que sempre faziam, como prova de amor. Ela disse que não. Que não se sentia preparada. Ele respondeu que entendia, mas que achava que ela não queria porque não gostava dele. Que até já devia ter feito isso com outro rapaz. E começou a gritar e a xingá-la. Ela tentava acalmá-lo perguntando-Ihe 
se ele havia esquecido que com ele tinha tido sua primeira transa. Ele não ouvia nada e no meio da discussão, deu-lhe uma bofetada e saiu batendo a porta.

Ela ficou inconsolável e, no dia seguinte, não foi à escola. Telefonou para sua melhor amiga, Suely e contou tudo a ela, chorando muito. Não sabia o que fazer. Não queria ceder ao desejo dele mas também não queria perdê-lo. Só que para ela, sexo anal era um problema. Devia doer muito... A amiga procurava consolá-la dizendo que "os homens são assim mesmo" e que se ele havia ficado tão nervoso era porque gostava muito dela e não queria perdê-la. Se ela fosse diferente com ele, poderia provar que o amava, etc etc etc.

No dia seguinte, assim que chegou à escola, Anabela foi parada por Ricardo que queria conversar com ela. Pediu milhões de desculpas, se disse muito arrependido e prometeu que nunca mais falariam naquilo. Ela acreditou nele, juraram amor eterno e foram para a casa dele.

Há dois dias, a enfermeira Joana foi procurada na UBS por Anabela que queria conversar sobre sexo anal. No meio da conversa, relatou toda a história à enfermeira.

\section{Diante desse relato, responda:}

1. O que você sente e pensa sobre esta situação?

2. Que problemas você identifica neste caso?

3. O que você acha que Joana deve fazer em relação a esta situação?

4. Que recursos existem na cidade que possam auxiliar a enfermeira Joana no seu atendimento?

5. Que ações são atualmente desenvolvidas no Município de Guarulhos para prevenir os problemas que você identificou nesta situação? 


\section{APÊNDICE 3}

\section{TERMO DE CONSENTIMENTO LIVRE E ESCLARECIDO}

Título do projeto: "Linha de cuidado para prevenção e enfrentamento da violência nas relações de intimidade entre adolescentes"

Orientadora: $\operatorname{Prof}^{\underline{a}} \operatorname{Dr}^{\mathrm{a}}{ }^{\mathrm{R}}$ Rosa Maria Godoy Serpa da Fonseca

Instituição de ensino: Escola de Enfermagem da Universidade de São Paulo (EEUSP)

O Sr (a) está sendo convidada a participar da pesquisa "Linha de cuidado para prevenção e enfrentamento da violência nas relações de intimidade entre adolescentes" de responsabilidade da pesquisadora Kátia Darbello da Silva.

O objetivo desta pesquisa é desenvolver uma linha de cuidado para prevenção e manejo da violência de gênero entre os adolescentes nas relações de intimidade, baseada nas políticas públicas existentes no Município de Guarulhos, para isso propusemos que responda um questionário a partir de uma situação apresentada. Esperamos com essa pesquisa contribuir para a melhoria das abordagens na prevenção e no atendimento da violência de gênero entre os adolescentes.

A participação é voluntária e este consentimento poderá ser retirado a qualquer tempo. A confidencialidade das informações e das respostas no questionário, bem como a privacidade do participante serão preservadas. Você receberá uma via deste documento com estas informações.

Em qualquer etapa do estudo, você terá acesso ao (s) pesquisador (es) responsável (eis) pela investigação para esclarecimento de dúvidas. O principal pesquisador é o (a) Sra. Kátia Darbello da Silva, que pode ser encontrado endereço Rua Anis Chakur, 66 - Jd. Alvorada -São Paulo - SP, pelo telefone (11) 99988-5248 ou e-mail: katitisss@yahoo.com.br

Esta pesquisa atende todas as especificações da Resolução 466, de 12 de dezembro de 2012 que aprova as diretrizes e normas regulamentadoras de pesquisas envolvendo seres humanos. 
Eu, $R G \mathrm{n}^{\circ}$

declaro ter sido informado e concordo participar, como voluntário, da pesquisa acima descrita.

de de

Assinatura participante

Assinatura pesquisador

Caso você tenha alguma consideração ou dúvida sobre a ética da pesquisa, entre em contato com o Comitê de Ética em Pesquisa (CEP) - Endereço - Av. Dr. Enéas de Carvalho Aguiar, 419 Cerqueira Cesar - São Paulo/SP CEP - 05403-000 Telefone- (11) 30618858 e-mail - cepee@usp.br 